Bond University

Research Repository

\title{
From Campbell to Hayne: W[h]ither Australia? Australian financial regulation and supervision at a cross-roads
}

Millhouse, David

Published in:

Law and Financial Markets Review

DOI:

10.1080/17521440.2019.1602696

Licence:

Other

Link to output in Bond University research repository.

Recommended citation(APA):

Millhouse, D. (2019). From Campbell to Hayne: W[h]ither Australia? Australian financial regulation and supervision at a cross-roads. Law and Financial Markets Review, 13(2-3), 81-98.

https://doi.org/10.1080/17521440.2019.1602696

\section{General rights}

Copyright and moral rights for the publications made accessible in the public portal are retained by the authors and/or other copyright owners and it is a condition of accessing publications that users recognise and abide by the legal requirements associated with these rights.

For more information, or if you believe that this document breaches copyright, please contact the Bond University research repository coordinator. 


\section{From Campbell to Hayne: W[h]ither Australia?}

\section{Australian Financial Regulation and Supervision at a Cross-Roads}

\section{Dr David G Millhouse}

Faculty of Law, Bond University, Australia

Correspondence: dmillhouse@millhouse.co

Dr David Millhouse is an Honorary Adjunct Senior Research Fellow, Faculty of Law, Bond University. This research paper contains material written for Dr Millhouse's $\mathrm{PhD}$ thesis entitled 'Systemic and cyclical failure in Australian financial services and financial products sectors: have weaknesses in law contributed to these failures?' That research was supported by an Australian Government Research Training Program Scholarship. This paper represents the views of the author only and does not purport to represent Bond University or its Faculty of Law. 


\title{
From Campbell to Hayne: W[h]ither Australia?
}

\section{Australian Financial Regulation and Supervision at a Cross-Roads}

\begin{abstract}
The Australian Government is in receipt of landmark advice: Heydon Royal Commission, ${ }^{1}$ Productivity Commission, ${ }^{2}$ and the Hayne Royal Commission. ${ }^{3}$ Each of them points to deep systemic and cyclical problems in the provision of financial products and financial services.

Whilst the Hayne Royal Commission identified egregious behaviour in banks and large financial institutions, far greater economic damage has occurred in less well known sectors of the Australian financial system. Australian law regulating and supervising Non-Bank Financial Entities (NBFEs) has failed those it purports to protect: the vulnerable investing public. Systemic failure manifests in extraordinary loss of investor funds and nationwide economic damage. Without substantial law reform, this author predicts systemic deficiencies in regulation will remain, repeating their cyclical manifestations.
\end{abstract}

Australia's plight is not unique but no other nation with a sophisticated economy now suffers comparatively. Blame is being attached to the basic policy framework whereas in fact it is policy implementation and enforcement that has allowed systemic failures to manifest.

Research demonstrates that inherent tensions between entrepreneurship and investor risk, optimal investor outcomes balanced with compliance, are not of themselves contradictory in a market based system, but they rely upon defining objectives, eliminating conflicts of objectives and conflicts of interest, significantly enhanced behavioural standards of market

${ }^{1}$ Commonwealth, Royal Commission into Trade Union Governance and Corruption (Interim Report, December 2014); Commonwealth, Royal Commission into Trade Union Governance and Corruption (Final Report, December 2015) (Commissioner Heydon).

${ }^{2}$ Australian Government Productivity Commission, Competition in the Australian Financial System (Draft Report, January 2018); Australian Government Productivity Commission, Superannuation: Assessing Efficiency and Competitiveness (Report No 91, 2018).

${ }^{3}$ Commonwealth, Royal Commission into Misconduct in the Banking, Superannuation and Financial Services Industry (2018) (Commissioner Hayne). 
participants, and the de-politicisation of the regulatory environment. This analysis demonstrates that fiduciary principles are misunderstood, applied haphazardly, often ignored, and subservient to specific statutory and contractual provisions.

Australia has a history of subsuming fiduciary principles behind statutory and contractual frameworks facilitating grudging disclosure and creeping corruption. Community expectations of what each market participant should do is often different from what they actually do.

Hayne's real message is the need to link law and morality, community norms and expectations with legal reality. 


\section{Introduction}

This is the story of modern Australia: why parts of the Australian economy struggle in a twenty first century globalised world. Australian industry is heavily dependent on non-bank financing: NonBank Financial Entities ${ }^{4}$ have filled these financing gaps.

[T] heir growth leads to a virtuous cycle through which countries benefit from broader access to financial services and a more competitive, diversified financial sector ... offer[ing] individuals and small- and medium-scale enterprises a broader menu of financial services ... creating jobs ... promot[ing] competition by introducing new industries that challenge the services and capacities of banks ...5

NBFEs include those entities providing financial advice and wealth management, bank controlled wealth management entities, non-bank financial products providers, collective investment schemes, investment managers, trustees, custodians, research houses, asset allocation consultants, securities brokers, securities platforms, hedge funds, insurance entities, finance companies, workers entitlement funds, and superannuation entities (public, industry, corporate, and Self-Managed Super Fund (SMSF)). Their main distinction is not being Authorised Deposit-taking Institutions (ADIs), and apart from some superannuation entities, not being prudentially regulated. These attributes set NBFEs apart from mainstream commercial banking, although many banks participate in NBFE markets through related party structures becoming vertically integrated financial conglomerates. Non-banks have also become financial conglomerates but have not been subject to prudential regulation. Some have been private or publicly listed vertically integrated multi-function financial entities; some are multinational financial services and funds management conglomerates; some

\footnotetext{
${ }^{4}$ NBFEs, sometimes referred to as Non-Bank Financial Institutions or NBFIs (a narrower term), colloquially known as shadow banking, terminology commonly used in other jurisdictions.

${ }^{5}$ Jeffrey Carmichael and Michael Pomerleano, 'The development and regulation of Non-Bank Financial Institutions' (Report, World Bank, 2002) xi.
} 
have been taken into public ownership given their local systemic importance. ' $[\mathrm{N}] \mathrm{o}$ unique classification of institutions provided is appropriate to all situations' ${ }^{6}$ Shadow banks may include some commercial activity within banks, being a 'broad definition that captures many forms of financial intermediation that are important for economic growth'?

NBFEs are sometimes categorised as 'investment banks'. This, and 'investment banking', are ill-defined terms. As Tuch notes, they can include, in the same entity: securities advice to wholesale and retail clients, underwriting, corporate advice, securities trading, investment research, securities dealing, corporate finance, asset management, private equity, hedge funds and foreign exchange trading. ${ }^{8}$

The influence of investment banks in the financial system and broader community is vast and their importance is increasing. The transactions on which they advise can have significant consequences for business competition and employment, often on an industry-wide or national basis. $^{9}$

Some become financial conglomerates. 'Financial conglomerates span industry domestic boundaries and international boundaries'. ${ }^{10}$ They also span regulatory jurisdictional boundaries. 'Modern financial intermediation processes add newer elements that do not always fit into the traditional silo based ways of ... market based-regulations ... or market-specific supervision. Reform approaches need to be more holistic'. ${ }^{11}$

${ }^{6}$ Ibid 5.

${ }^{7}$ Stijn Claessens and Laura Kodres, 'The Regulatory Responses to the Global Financial Crisis: Some uncomfortable questions' (Working Paper No 14/46, International Monetary Fund, March 2014) 19.

${ }^{8}$ Andrew Tuch, 'Investment Banks as Fiduciaries: Implications for Conflicts of Interest' (2005) Melbourne University Law Review 478, 486.

${ }^{9}$ Ibid 484.

${ }^{10}$ Jeffrey Carmichael, 'Regulatory lessons from the Crisis: A view from Down Under' (Presentation to OECD/ADBI Roundtable, February 2010); see also, Mohamed Ariff, John H Farrar and Ahmed M Khalid (eds), Regulatory Failure and the GFC - An Australian Perspective (Elgar Online, 2012) ch 12.

${ }^{11}$ Claessens and Kodres (n 7) 4. 
With limited exceptions, none of the entities categorised as conglomerates in this author's empirical analysis are ADIs. The exceptions are multi-function holding entities which have acquired or control an ADI (eg a building society, general insurer). ADI functions of banking conglomerates which control financial planning and wealth management entities are excluded from the analysis.

NBFEs, however categorised are socially important and underpin the operation of the modern economy in Australia and elsewhere. They are systemically important and 'may contribute to the build-up of systemic risk and severity of financial crises'. ${ }^{12}$ These risks have included runs on funds and contagion. Other authors agree: 'Systemic risks emerged, yet went undetected or not addressed for some time and then created great havoc'. ${ }^{13}$ This author's empirical analysis illustrates the point. Tuch notes the 'social repercussions and its public dimensions'. ${ }^{14}$

Many NBFEs have been and are of the size and systemic importance that the regulatory distinctions between ADIs and non-ADIs, and between ex ante supervision and ex post market conduct, may be obsolete and should be reviewed. The Australian superannuation asset base is larger than that of its banking system and heavily exposed to other NBFEs.

\subsection{The Law Matters}

The law matters. 'The law can facilitate economic development and not simply coerce, regulate and control'. ${ }^{15}$ This maxim is being lost in present day Australian NBFE regulation and needs to be

\footnotetext{
${ }^{12}$ Elias Bengtsson, 'Fund Management and Systemic Risk - Lessons from the Global Financial Crisis' (2014) 23(2) Financial Markets, Institutions and Instruments 101.

${ }^{13}$ Claessens and Kodres (n 7) 4.

${ }^{14}$ Tuch (n 8) 505 citing Charles R Geisst, Investment Banking the Financial System (Prentice Hall Business Publishing, 1995) 1.

${ }^{15}$ Justice Michael Kirby, 'The company director: past, present, and future' (Speech delivered at the Australian Institute of Company Directors, Tasmanian Division, Hobart, 1998).
} 
recovered since it can also have the opposite result. There is 'a positive relationship between financial sector functions and economic growth'. ${ }^{16}$ 'Law Matters' means a jurisprudence regime which allows investors to feel confident of expected economic outcomes, uncorrupted by the political milieu. Is this the case in Australia today where significant numbers and groups of investors lack confidence in financial entities and their regulators? '[T] he state should create the framework - the rules of the game for the economy'. ${ }^{17}$

The general legal framework is arguably the single most important determinant of a sound NBFI[E] sector. Legislation underpinning the specific framework for NBFIs [E's] is the foundation of good regulation ... There should be no ambiguity. ${ }^{18}$

[C]ountries that lack a coherent policy framework and effective regulations, nonbank financial institutions [NBFEs] such as insurance, leasing and finance companies, and collective investment vehicles, can exacerbate the fragility of the financial system. This fragility is often the result of a conscious effort to arbitrage and circumvent banking regulations. ${ }^{19}$

The Law Matters thesis 'constitutes the crucial bedrock' that underpins economies. ${ }^{20}$ This author's empirical analysis proves that law matters in NBFE regulation, supervision and governance including the selective application and enforcement of present law. ${ }^{21}$

Policymakers should create a regulatory environment that provides a platform for diffuse securities ownership which may then deliver superior economic results. This underpins a modern

\footnotetext{
${ }^{16}$ Carmichael and Pomerleano (n 5) 12 citing Ross Levine, Norman Loaya and Thorsten Beck, 'Financial Intermediation and Growth: Causality and Causes' (World Bank Development Research Group, 1999).

${ }^{17}$ Matthew Qvortrup, Angela Merkel Europe's most influential leader (Duckworth Overlook, 2017) 338.

${ }^{18}$ Carmichael and Pomerleano (n 5) 198.

${ }^{19}$ Ibid 19.

${ }^{20}$ Ibid 346.

${ }^{21}$ Evan Jones, 'CBA, ASIC and the political class: partners in crime', Independent Australia, 7 July 2014 $<$ http://www.independentaustralia.net/.../cba-asic-and-the-political-class-partners-in-crime $>$.
} 
economy. ${ }^{22}$ Why should the law matter? To whom does the law matter? 'The essential insight underlying the 'law matters' thesis is that, in an unregulated environment, there is a real danger that a company's 'insiders' (controlling shareholders and senior executives) will cheat outside investors who own equity'. ${ }^{23}$

Indeed, this author's empirical legal analysis of Australian NBFE related party transactions supports that insight. Expropriation of value also occurs by tunnelling, ${ }^{24}$ being non-related party transactions, addressed extensively in Germany and the EU through codified civil law duties of care and loyalty. Egregious transfer of shareholder value is facilitated by the narrow interpretation of fiduciary duty and the limited universe to which it is applied in Australia.

The Law Matters thesis is not without its critics: 'the historical experience in the US and the UK [casts] doubt on whether law is as pivotal and the thesis implies' ${ }^{25}$ Its basic premise 'seems irrefutable, but how much it matters indeed, is a matter of much conjecture'. ${ }^{26}$ In practice, the 'law is one of many influences that shape economic development ... differences in the nature and effectiveness of a country's financial system depend on investor protection.' ${ }^{27}$ But the law is not the

\footnotetext{
${ }^{22}$ Brian R Cheffins, 'Corporate Law and ownership structure: A Darwinian Link?' (2002) 25(2) University of New South Wales Law Journal 346, 347, citing Adolf Berle and Gardiner Means, The Modern Corporation and Private Property (Transaction, 1932).

${ }^{23}$ Brian R Cheffins, 'Law as Bedrock: The Foundations of an Economy Dominated by Widely Held Public Companies' (2003) 23(1) Oxford Journal of Legal Studies 1, 6.

${ }^{24}$ Li-Anne Elizabeth Woo, 'The Importance of the Law Matters Thesis' (2006) 3(4) Corporate Ownership \& Control 219, 221, citing Simon Johnson, Rafael La Porta, Florencio Lopez-de-Salines and Andrei Shleifer, 'Tunnelling' (NBER Working Paper No 7523, 2000) 12.

${ }^{25}$ Cheffins (n 23).

${ }^{26}$ Woo (n 24) 226.

${ }^{27}$ Ibid 220.
} 
only factor. ${ }^{28}$ To whom law matters, which law matters and options for its future development are proposed in this paper.

\subsection{Historical Background}

The story of modern Australia is a history of accretive statutory reform designed to promote economic development circumvented and corrupted by malfeasors using legal uncertainties and omissions to further their own interests. The accretive culture, fragmentation and complexity of Australian law leads to uncertainty, ambiguity, and enforcement deadweight costs for investor and regulators. If Australia wishes to pursue an agenda of increasing living standards based on agility and innovation, then law reform is an essential pre-condition.

Traditional assumptions that private investors are rational, accessing and applying all disclosed information are false. More modern behavioural economics theory, ${ }^{29}$ leads to different conclusions and different regulatory postures. Behavioural economics recognises that investor biases and irrationality, often on the same set of disclosed facts in 'complex situation-dependent ways', ${ }^{30}$ lead to different behaviours and decisions. This need not, nor should it as some suggest, provide an excuse for further government intervention. It does emphasise a community need for financial literacy competencies and a regulatory posture that treats investors as financial consumers learning from their financial advisers who tutor them in teachable moments.

Australia is a global outlier in many important aspects of its NBFE regulation, although not alone in its original Twin Peaks architecture. It does not follow international standards and practice.

\footnotetext{
${ }^{28}$ Katharina Pistor, 'Rethinking the "Law and Finance” Paradigm' (2009) Brigham Young University Law Review 1647, 1669.

${ }^{29}$ See, eg, the work of Richard H Thaler, Robert J Shiller, and Xavier Gabaix; R Thaler and C Sunstein, Nudge: Improving Decisions about Health, Wealth and Happiness (Yale University Press, 2008) 7.

${ }^{30}$ Noah Smith, 'Wanted: A Unifying Theory of Behavioural Economics' (6 January 2018) $<$ https://www.bloombergquint.com/onweb/2018/01/05>.
} 
Specifically, it is almost unique in the use of trusts as large commercial trading enterprises, low licencing and capitalisation barriers to entry, limited fit and proper competency requirements, nonadherence to many International Organization of Securities Commissions (IOSCO) and Markets in Financial Instruments Directive (MiFID) $1 \& 11$ provisions, regulation of custody, its poachergamekeeper model for collective investment schemes (Managed Investment Schemes or MIS), and mismatch between trust law and modern portfolio theory.

Its corporate governance regime has often failed those it purports to protect: the investing public. Failure is not rare. Remediation is costly, of limited financial veracity, with significant time elapsed to achieve limited results. Systemic and cyclical failures are found in the implementation of each element of the Wallis ${ }^{31}$ market model reforms (ie disclosure, advice, and financial literacy) of 1997, including inter alia, financial adviser licencing, the Managed Investments Act and the Future of Financial Advice (FoFA) reforms. There is limited commonality of view ${ }^{32}$ and public questioning of some of the basic tenets upon which Australia's regulation of financial products and services is based. Market conduct regulation largely deals with problems after the event: unlike prudential supervision it doesn't prevent them (not always successfully). Blame is being attached to the basic policy framework. But it is incomplete policy implementation and poor governance that has allowed systemic problems to manifest themselves. This unveiling 'inspired a tornado of excoriating criticism of financial markets and their participants' ${ }^{33}$ Corporate governance is the implementive cousin of market conduct regulation: prudential supervision is its sibling, accompanied by familial moral hazard.

This research identifies more than 1,915,608 investors in Australia who have been financially damaged by corporate failures in NBFEs. Direct aggregate reported negative financial

\footnotetext{
${ }^{31}$ S Wallis, Australian Financial System Inquiry Final Report (Australian Government Publishing Service, March 1997).

${ }^{32}$ Kevin Davis, 'Study of Financial System Guarantees' (Australia Treasury, 2004) ch 2.

${ }^{33}$ M Scott Donald, 'Regulating for fiduciary qualities of conduct' (2013) 7(2) Journal of Equity 142.
} 
impacts are estimated to be at least AUD52.25 billion over the study period (1981-2018). This lost capital is equivalent to c $0.46 \%$ of $2016-17$ nominal Australian GDP. More importantly, because it is a cumulative misallocation of capital, it implies a foregone GDP growth rate of c $23.14 \%$ p.a. assuming GDP represents all Australian economic activity. Consistently, EU law reform of retail investor capital markets was estimated to increase EU GDP by 'between 0.5 and $0.7 \%$ [pa]. ${ }^{34}$ The essential insight is that the cumulative misallocation of capital in aggregate - the opportunity cost - causes lower economic growth. This is particularly so because NBFE financing is at the margin — it finances projects that would not otherwise occur including in regional areas.

This data does not include consequential financial losses or other personal consequences. These losses are not aberrations. The Australian Securities and Investments Commission (ASIC) estimate that c AUD66.00 billion has been lost by investors in GFC related collapses from 20079. ${ }^{35}$ These losses include entities that are not NBFEs. It can be misleading to blame the GFC for failures which should properly be attributed to other causes. The GFC merely exposed underlying systemic weaknesses. For instance, ASIC also estimate that c AUD20.00 billion of retail investment funds in NBFEs were 'frozen', ${ }^{36}$ some never to be recovered.

Despite scholarly observations of 'reasonable expectations' in $2005^{37}$ and some tactical regulatory change, very little has been implemented that would prevent another major collapse or

${ }^{34}$ Friedrich Heinemann and Mathias Jopp, 'The benefits of a Working European Retail Market for Financial Services: Report to European Financial Services Round Table' (Institute für Europäische Politik, Berlin, 2002); See especially, Niamh Moloney, 'Building a Retail Investment Culture through Law: The 2004 Markets in Financial Instruments Directive' (2005) 6 European Business Organisation Law Review 354 citing ZEW/IEP, 'The Benefits of a Working European Retail Market for Financial Services' (Report, European Financial Services Round Table, 2002).

${ }^{35}$ Tony D'Aloisio, 'Responding to the global financial crisis: the ASIC Story' (Speech delivered at the Trans-Tasman Business Circle, 30 November 2010).

${ }^{36}$ Ibid.

${ }^{37}$ Tuch (n 8) 478, 482 citing Paul Finn, 'Contract and the Fiduciary Principal' (1989) 12 University of New South Wales Law Journal 76, 84. 
scandal involving a NBFE. Failure has been and will be cyclical. These failures arise from a number of systemic causes. These include: flawed business models; related party transactions and conflicts of interest; poor investor outcomes arising from conflicts of economic objectives through tunnelling; complete loss through legally compliant financial products and procedures; deceptive and misleading conduct; fraud; and under capitalisation. These manifestations of systemic failure arise from uncertainties in the law, practical impediments to its application, lack of harmonisation between sources of law, and lack of investment economic objectives being an integral part of the body of law in superannuation and non-superannuation environments. These factors lead to arbitrage opportunities for those inclined to mal-, mis-, or non-feasance. Australians (compulsorily) invest in an environment of a multitude of complex financial products (direct, corporate and superannuation) but are not afforded the protections they assume are there.

Subsequent regulatory response has been directly related to the degree of public pressure from those aggrieved seeking remedies as a result of a crisis, or a report driven by economic policy objectives. Many of the responses have been lacking insight and are mostly tactical. ${ }^{38}$ However, these are not new issues: 'the events of the late 1980s and early 1990s portrayed a failure of law, policy, and ethics'. ${ }^{39}$ The law provides the architecture and it can mitigate investor risk. Since NBFEs are derivative exposures of the underlying real economy, the law of itself cannot prevent the underlying attrition of those market linked assets. However, for some superannuation entities, Australian law now provides that directors and trustees must take into account market and longevity risks.

Shifting policy sands, constantly changing regulation, regular judicial review, and subsequent statutory responses make it extraordinarily difficult for a non-professional director, a

\footnotetext{
${ }^{38}$ Chief Justice Paul de Jersey, 'Developments in Financial Services Law of the last 30 years' (Speech delivered at the Banking and Finance Services Law Association 30th Annual Conference, Gold Coast QLD, Australia, 30 August 2013).

${ }^{39}$ Kirby (n 15).
} 
director of a corporate trustee, or a trustee in person, to either understand the law or to properly discharge their duties. The present difficulty for regulatory reform in Australia is vested interest with differing objectives influencing a volatile political milieu.

Judicial review has led the way in the development and enforcement of present law, noting the need for statutory reform. Judicial opinion has been scathing about the deficiencies and uncertainties in the law regulating Australian financial products and financial services. ${ }^{40}$ Other legal opinion is equally severe: 'overly prescriptive, complex and poorly drafted [PDS]: The regime relies upon definitions within definitions and exceptions within exceptions. It is difficult for lawyers to get their heads around - let alone investors lacking in legal training, ${ }^{41}$

Australian law has been demonstrably deficient, especially compared with some comparative jurisdictions such as Canada, Germany and Singapore. Australian investors, other participants in the investment chain, and the broader economy have suffered as a result. Statutory reforms alone, whilst superficially attractive given the relative ease of implementation, have not and will not resolve systemic deficiencies in regulation nor their cyclical manifestations.

${ }^{40}$ See, eg, Rich v Australian Securities and Investments Commission [2004] HCA 42 [122] (Kirby J); Wingecarribee Shire Council v Lehman Brothers Australia Ltd (in Liq) [2012] FCA 1028 Summary 3 (Rares J); Australian Securities and Investments Commission v Australian Property Custodian Holdings Limited (Receivers and Managers appointed) (in liquidation)(Controllers appointed)(No 3) [2013] FCA 1342 (12 December 2013) [463] (Murphy J); Re Environvest Ltd (No 4) [2010] VSC 549 [2]-[3] (Judd J); Aequitas v AEFC [2001] NSWSC 14 [363] (Austin J); Australian Softwood Forests Pty Ltd v Attorney-General (NSW); Ex Rel Corporate Affairs Commission [1981] HCA 49 [37] (Murphy J); Australian Securities and Investments Commission v Bridgecorp Finance Ltd [2006] NSWSC 836 [17] (Barrett J) citing Australian Securities and Investments Commission v Mauer-Swiss Securities Ltd [2002] NSWSC 684 (Palmer J); Trilogy Funds Management Limited v Sullivan (No 2) [2015] FCA 1452 [1] (Wigney J); ASIC v Vines [2006] NSWSC 738 [14] (Austin J).

${ }^{41}$ Garry T Bigmore and Simon Rubenstein, 'Rights of Investors in Failed or Insolvent Managed Investment Schemes' in Stewart J Maiden (ed), Insolvent Investments (LexisNexis Butterworths, 2015) 238. 


\subsection{Creeping Corruption in Australian NBFEs}

Creeping corruption, sometimes arising from grudging disclosure, aided by uncertain and complex law, poor advice and unknowledgeable investors is systemic in the Australian NBFE sector. This has resulted in investor disbelief and in some cases, significant judicial interventions. '[C]omplex legislation may mean that for those who deliberately seek not to comply with the law, they can readily do this...' ${ }^{42}$ This has not been restricted to Australia: in the UK, such sentiments are expressed as creative compliance. UK legislative recognition of the economic importance of Small and Medium-sized Enterprises (SMEs) was a driver of statutory reform ${ }^{43}$ to meet the 'reasonable expectations of business people so that regulatory traps for the unwary are avoided' ${ }^{44}$ Directors, particularly of private companies were considered not to be able to understand their duties.

In Australia creative compliance or creeping corruption occurs where statutory provisions are interpreted narrowly and corruption escapes close scrutiny. In the longer term, this subverts the economic interests of investors and beneficiaries. The economic interests of investors and beneficiaries supported by holistic fiduciary standards in the investment chain is a different proposition from compliance with regulation. It leads to a different result: 'It [Creative Compliance] is essentially the practice of using the letter of the law to defeat its spirit, and to do so with impunity'. ${ }^{45}$

Australian regulation of financial products and financial services requires substantive law reform and reforms designed to enhance productivity in the economy. Without substantive reform,

\footnotetext{
${ }^{42}$ Hui Xian Chia and Ian Ramsay, 'Section 1322 as a response to the complexity of the Corporations Act 2001 (Cth)' (2015) 33 Companies \& Securities Law Journal 389, 394.

${ }^{43}$ Companies Act 2006 (UK).

${ }^{44}$ John Lowry, 'Codifying the corporate opportunity doctrine: The (UK) Companies Act 2006' (2012) 5 International Review of Law 1, 3.

${ }^{45}$ Simon Ashby, 'The Turner Review on the Global Banking Crisis: A Response from the Financial Services Forum' (Nottingham University, 2009) 17.
} 
there will be no remedy of the systemic deficiencies in regulation nor of their cyclical manifestations which harm productivity.

Regulation can influence the growth of NBFIs[-Es] in two main ways: (a) repressive regulation can retard NBFI growth, and (b) inappropriate regulation or poorly designed regulatory structures can stimulate NBFI[-E] growth for the wrong reasons, often creating incentives for regulatory arbitrage and the emergence of unanticipated systemic problems. ${ }^{46}$

Australian law permits the contracting out of fiduciary obligations. In retail financial advice, the Corporations Act subsumes general law fiduciary obligation beneath regulatory process, the result being a mismatch of community fiduciary expectation with industry practice. In superannuation, statutory intervention excludes access to the 'general law relating to conflict of interest' ${ }^{47}$ Consequently, significant numbers of investors in Australia today have lost their trust in the financial system. Community expectations of, and trust in what each market participant should do is often different from what they actually do. These ambiguities have led investors to a false sense of security which was sadly and damagingly misplaced. Whilst Australia has benefited from its Twin Peaks market based regulatory system (posited by this author to be 'Triple Peaks', given the integral role of the industrial system in superannuation savings), ${ }^{48}$ and has arguably progressed toward the first objective of an entrepreneurial wealth creating society competing with its global peers in many asset classes, the second objective, being investment stability and risk mitigation, has for many people been an abject disaster.

This author's empirical analysis quantifies those direct losses and analyses the economic consequences to the nation. It demonstrates that failure is predictable, cyclical, and has deep legal

\footnotetext{
${ }^{46}$ Carmichael and Pomerleano (n 5) 208.

${ }^{47}$ Superannuation Industry (Supervision) Act 1993 (Cth) s 58B.

${ }^{48}$ See below, 'Australia's Triple Peaks regulatory architecture'.
} 
systemic roots. ${ }^{49}$ This empirical data points to failures of law on a massive scale. It also points to legal solutions to the problem of anti-entrepreneurial repressive legislation (accretive statute) and to solutions to unanticipated systemic failures particularly of vertically integrated NBFEs in a consolidating market. These solutions can also be applied to NBFE entities associated with commercial banks. There has been no quantitative assessment of the costs to the economy of legal complexity and uncertainty. These costs include compliance, director and trustee insurance, limited mutual recognition through lack of harmonisation, reduced capital inflows, reduced real economy investment, and reform fatigue. ${ }^{50}$

Some might argue reform solutions will reduce the entrepreneurial capacity of the Australian economy. The contrary is the case. Restore the trust and the economy will respond. The economic losses directly incurred by investors and beneficiaries, added to foregone investment that may have taken place, has resulted in Australia having an economy reliant less upon domestic savings and more upon foreign capital to finance new business investment. The reform objective must be to re-establish trust, confidence and respect, which has been lost in several decades of often anonymous or poorly-informed financial product selling to vulnerable retail investors, despite repeated analysis and with similar conclusions from $2001 .^{51}$

Reform requires significant elapsed time, probably a decade, and it must be sequenced. Strategic reform requires acceptance and implementation by the various stakeholder groups. Tactical reforms can be imposed legislatively. The effectiveness and stability generated by prudential supervision needs to be embedded as a governance value system - a culture - within the

\footnotetext{
${ }^{49}$ David G Millhouse, 'Systemic and Cyclical Failure in Australian Financial Services and Financial Products Sectors: Have weaknesses in law contributed to these failures?' (PhD thesis, Bond University, 2019) ch 3 tab 3.25.

${ }^{50}$ Hui Xian Chia and Ian Ramsay, 'Section 1322 as a response to the complexity of the Corporations Act 2001 (Cth)' (2015) 33 Companies \& Securities Law Journal 389, 403.

${ }^{51}$ Lord Myners, United Kingdom HM Treasury, Institutional Investment in the UK: A Review (March 2001).
} 
non-prudentially regulated NBFE sector. Successful implementation aligns interest of provider and consumer: it also changes the role of the regulators: they become educators, supervisors. A healthy culture results in enforcement becoming a last resort.

\subsection{Reform Implementation Objectives}

The neo-classical market model as envisaged by Campbel1 ${ }^{52}$ and Wallis sought to create a regulatory environment that led to investment opportunities that did not exist previously and may not otherwise have existed at all. Given the societal need for a sound NBFE sector, these market freedoms were not matched by effective implementation of the strategic underpinnings of Wallis, being disclosure, advice, and investor empowerment and knowledge through education, nor in many cases, corporate governance responsibility and ethical standards enforced by the application of fiduciary principles.

Australia has not been alone in seeking to implement reform of its financial sectors. There are and will be contested reform agendas. These include the tension between investor empowerment and libertarian paternalism. ${ }^{53}$ Their resolution will depend on acceptance of the reasons for failure. International precedent provides a framework, offering three options. ${ }^{54}$ Were the Wallis and other Australian market reforms faulty, or was their implementation faulty (if only because of political constraints)? Were there sequencing issues, or a simplification of the links between desired economic outcome and legal reform? Were the reforms incomplete? ${ }^{55}$

\footnotetext{
${ }^{52}$ Sir Keith Campbell, Committee of Inquiry into the Australian Financial System (Australian Government Publishing Service, Cat No 8104251, Canberra, 1981).

${ }^{53}$ Jeremy Cooper, Review of the Governance, Efficiency, Structure, and operation of Australia's Superannuation System (Commonwealth of Australia, 30 June 2010).

${ }^{54}$ Nancy Birdsall, Augustus de la Torre and Felipe Valencia Caidedo, The Washington Consensus Assessing a Damaged Brand (The World Bank Policy Research Working Paper, 5316, May 2010) 21.

${ }^{55}$ The Washington Consensus is a package of economic policy objectives, including deregulation of financial sectors, designed to promote economic development in emerging economies. See especially
} 
Analysis, in a different but comparable context, 'blames the poor post-reform outcomes on uneven and incomplete reform implementation'. ${ }^{56}$ Political interest generates contested reform implementation in Australia. Similarly, in the US, trade protectionism since 2016 challenges the Washington Consensus and is inconsistent with delayed reform and statutory repeal in its financial services markets, or indeed the rollback of previous reform. ${ }^{57}$ Whatever the architecture, political constraints to reform implementation come at a price to the financial consumer.

\subsection{Four Distinctive Periods}

The history of the development of the law of the Australian financial services and products regulatory sector would be incomplete without an understanding of the economic conditions which drove the development of the legal framework. This framework can be divided into four primary periods: The Age of Entrepreneurship and Deregulation (1981-2001), The Age of Disquiet (20022009), The Age of Reaction (2010-2013) and the Age of Statutes and Compliance (2014 et seq). It illustrates the tension between market based principles of Australian financial system regulation and those that oppose or seek to modify a market based approach, these tensions embedded in Australian statutes.

John Williamson, 'A Short History of the Washington Consensus' (Paper presented at the conference 'From the Washington Consensus towards a new Global Governance', Barcelona, 24-25 September 2004).

${ }^{56}$ Birdsall, de la Torre and Caidedo (n 52) 22 citing Agnes A Belaisch et al, Stabilisation and Reform in Latin America; A Macroeconomic Perspective of the Experience Since the 1990s (International Monetary Fund, Occasional Papers No 238, 2005). See also Anne O Krueger, 'Meant Well, Tried Little, Failed Much: policy Reforms in Emerging Market Economies' (Speech delivered to the Economic Honours Society, New York University, New York, 23 March 2004).

${ }^{57}$ See, eg, Nicolas J Firzli, 'Understanding Trumponomics' (26 January 2017), Revue Analyse Financière $<$ http://analysefinanciere.org/2017/01/26/understanding-trumponomics/>. 
Relevant law includes a number of statutes and their interaction with the general law. The primary legislative instruments which seek to regulate director, officer, and trustee responsibility for the governance of NBFEs are the Corporations Act, ${ }^{58}$ Superannuation Industry (Supervision) Act, ${ }^{59}$ and the Fair Work (Registered Organisations) Amendment Act. ${ }^{60}$ The three primary regulators are subject to their own legislation: $A S I C A c t^{61}$ (market conduct), $A P R A A c t^{62}$ (prudential supervision), and Fair Work $A c t^{63}$ (the link between Australia's industrial and superannuation systems). As Murray $^{64}$ and Heydon ${ }^{65}$ demonstrate, this interface is largely unexplored territory, resulting in Australia being an outlier in financial regulation. The much vaunted 'Twin Peaks' in effect becomes 'Triple Peaks' with as yet unknown consequences. There is considerable additional relevant legislation including the Competition and Consumer Act. ${ }^{66}$ There are sectoral governance rules and standards, ${ }^{67}$ and Codes of Conduct, proposed by Hayne to be enforceable. ${ }^{68}$

\footnotetext{
${ }^{58}$ Corporations Act 2001 (Cth).

${ }^{59}$ Superannuation Industry (Supervision) Act 1993 (Cth).

${ }^{60}$ Fair Work (Registered Organisations) Amendment Act 2016 (Cth).

${ }^{61}$ Australian Securities and Investments Commission Act 2001 (Cth).

${ }^{62}$ Australian Prudential Regulatory Authority Act 1998 (Cth).

${ }^{63}$ Fair Work Act 2009 (Cth).

${ }^{64}$ David Murray, Financial System Final Report (Australia Treasury, 2014).

${ }^{65}$ Commonwealth, Royal Commission into Trade Union Governance and Corruption (Final Report, December 2015) (Commissioner Heydon).

${ }^{66}$ Competition and Consumer Act 2010 (Cth).

${ }^{67}$ John Farrar and Pamela Hanrahan, Corporate Governance (Reed International - LexisNexis Butterworths, $\left.1^{\text {st }} \mathrm{ed}, 2017\right)$ [30.2].

${ }^{68}$ Hayne (n 3) rec 1.15.
} 
- Prudential supervision of ADI's, insurance \& superannuation

- $\quad$ Financial system stability

- Monetary policy

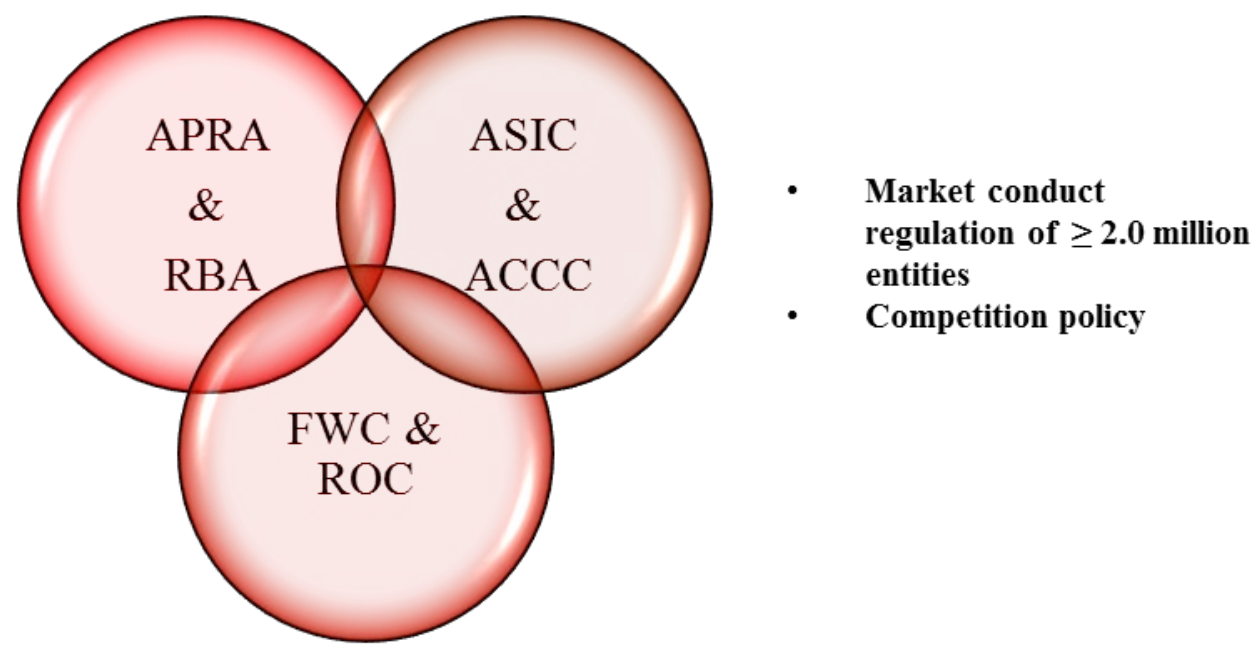

- Registered organisation regulation

- Interface between industry, compulsory superannuation $\&$ financial systems 


\section{Preparing for the Future}

Australian law and regulation of financial products and services has largely developed in response to crises and public policy imperatives. ${ }^{69}$ These

[c]rises are more likely to reveal critical features of a complex system that remains undetected in the normal state. The purpose of a crisis analysis is not primarily to understand the cause of a specific corporate governance failure, but to learn about the system in which this failure occurred. ${ }^{70}$

Hayne is the latest significant extra-curial and judicial writing, followed by legislative reform of statutes. The 'institutional autops[ies] ${ }^{71}$ of major cases have steadily, if haphazardly, focussed and enhanced the duties of directors and trustees with a plethora of judicial interventions over this period in response to the cyclical nature of the underlying systemic problems unearthed. In Australia,

[t]he law regulating managed investment schemes (and other commercial trusts) remains seriously inadequate, a situation that should be regarded as intolerable in respect of entities that are permitted to raise funds from the public ... Australian trust law ... suffers fundamental structural weaknesses as a system for regulating large and complex enterprise entities. ${ }^{72}$

Reform needs: 'a system-wide perspective explicitly aimed at addressing market failures; understanding and incorporating into regulations agents' incentives so as to align them better with

\footnotetext{
${ }^{69}$ de Jersey (n 38).

${ }^{70}$ Pistor (n 28) 1666.

${ }^{71}$ Ibid.
}

${ }^{72}$ Nuncio D'Angelo, 'The CAMAC Report on managed investment schemes: Another opportunity missed?' (2012) 23 Journal of Banking and Finance Law and Practice 253, 254. 
societies' goals... ${ }^{73}$ and resisting 'fine tuning regulations' ${ }^{74}$ Hayne agrees, ${ }^{75}$ providing limited specific recommendations but importantly, emphasising the need for wider reform.

'The sad news is that the general approach to reforms [ha]s largely still been based on an outmoded and by now largely repudiated conceptual concept of regulations, which does not start from the "system-wide" characteristics of risks and often misses key risks'. ${ }^{76}$

The starting point for Australian reform is where empirical analysis identifies a $90 \%$ greater or equal correlation between selected variables. ${ }^{77}$ Related party transactions and misleading and deceptive conduct are closely correlated (93.42\%). This Tactical implementation can be achieved through the harmonisation of directors and trustee duties, reform of the use of trusts as commercial investment entities, and the international harmonisation of Australian corporate governance and financial product standards.

Specifically, the International Organization of Securities Commissions (IOSCO), Financial Stability Board (FSB), MiFID 1 and 11, embrace of the Global Corporate Governance Standard, ${ }^{78}$ licensing and capitalisation, and asserting the primacy of fiduciary and fiduciary-like responsibility. Consistency between in-country reforms and globally is sound policy. To not achieve at least these results risks the Australian NBFE funds management industry becoming a global outlier with negative economic consequences. These strategies may also render reform less politically

${ }^{73}$ Claessens and Kodres, above n 7, 2.

${ }^{74}$ Ibid.

${ }^{75}$ Commonwealth, Royal Commission into Misconduct in the Banking, Superannuation and Financial Services Industry (2018) (Commissioner Hayne) vol 1 494-496.

${ }^{76}$ Claessens and Kodres, above n 7, 4.

${ }^{77}$ David G Millhouse, 'Systemic and Cyclical Failure in Australian Financial Services and Financial Products Sectors: Have weaknesses in law contributed to these failures?' ( $\mathrm{PhD}$ thesis, Bond University, 2019) ch 3, app 2.

${ }^{78}$ Centre for Fiduciary Excellence LLC and fi360 Inc 11, 'Prudent Practices for Investment Managers: Defining a Global Fiduciary Standard of Excellence' (2013 Worldwide edition). 
contentious. IOSCO has a well-defined assessment and implementation process including for market confidence and integrity, investor protection, and reduction of financial crime. ${ }^{79}$

Risks will remain: 'a fully "fail-proof” financial system may not be the most efficient in delivering economic growth or other desirable outcomes', ${ }^{80}$ including the development of financial literacy competencies as an alternative to libertarian paternalism. There could be 'less emphasis on formal rules and give more discretion to [reformed] supervisory agencies ... perhaps avoid the proliferation of rules that may add more costs than they provide benefits and may even increase overall risks', ${ }^{81}$ a suggestion consistent with this author.

Harmonisation includes the need to address the scope and importance of applying fiduciary principles to governance of the NBFE sector. The objective should be quality assurance of the investment chain for the benefit of the financial consumer. This is an accepted principle in other scholarly disciplines. The duties and responsibilities of directors and directors of trustees and registered organisations are not consistent across the Corporations Act, Superannuation Industry (Supervision) (SIS) Act, and Fair Work (Registered Organisations) Amendment Act. Presently, there are differing statutory interventions ranging from none to significantly prescribed statutory fiduciary duties in the governance of superannuation entities, a greater statutory intervention than embodied in the Corporations Act. The backgrounds of directors and trustees influence their understanding of and implementation of fiduciary principles, and the personal risks they assume arising from these roles.

Inconsistencies in the law have led to opportunistic behaviour by some directors and trustees. Whilst arguably complying with statute, they do not follow the spirit of the law and do not optimise investor outcomes. In some cases, despite the provisions of statutes and general law,

\footnotetext{
${ }^{79}$ IOSCO, Impact Assessment Guidelines (July 2011) [1.5].

${ }^{80}$ Claessens and Kodres (n 7) 12.

${ }^{81}$ Ibid 23.
} 
shareholders and unitholders have been asked to approve, usually through a sequence of transactions, often between related parties including directors and entities controlled by them, outcomes which are suboptimal and which enrich those who govern the NBFE. Sober analysis reveals outcomes which, had they been concluded in a single transaction, would be prima facie cases of non-, mis- and malfeasance.

The law governing the supply of financial products and services by NBFEs is a field where opposing political, social, and economic interests compete intensively. ${ }^{82}$ NBFEs and their regulators operate in a political milieu. It is assumed that there is a level playing field in Australian regulation. This may not be the case. Some NBFEs have better access to agents of the state than others and governance structures that can influence political outcomes unavailable to others. ${ }^{83}$

\footnotetext{
82 de Jersey (n 38).

${ }^{83}$ Cheffins, 'Corporate Law and ownership structure' (n 22) 361.
} 


\section{The Economic Effect of Inaction}

The financial system is based on trust. ${ }^{84}$ Hayne notes ' $[\mathrm{r}]$ arely, if ever, was there explicit examination of, or comparison between, the costs of doing nothing and the costs and consequences of changing the rules' ${ }^{85}$ This empirical analysis has now been undertaken. ${ }^{86}$

There is a considerable historical literature on the relationship between law and economics. These include assertions of efficiency and inducement of efficiency of common law based on judicial interpretations of fairness, justice, and rights $;{ }^{87}$ legislative capture by special interest groups; ${ }^{88}$ the economics of models of regulation; ${ }^{89}$ and legal empirical analysis. ${ }^{90}$ 'There is a very general need for empirical work on the legal system to be undertaken'. ${ }^{91}$ That includes definition of efficiency: economists apply consumer welfare benefit rather than legal efficiency. In Australia, examples of legislative capture include the FoFA and registered organisation reforms, both contested by interest groups and politicised. Reform of superannuation fund governance remains contested. Each of these examples should be subjected to the spotlight of empirical legal analysis to improve economic outcomes for their respective financial consumers.

\footnotetext{
${ }^{84}$ Chris Bowen, 'Overhaul of Financial Advice' (Media Release No 036, 26 April 2010).

${ }^{85}$ Hayne (n 3) vol 117.

${ }^{86}$ Millhouse (n 49) ch 3 app 2.

${ }^{87}$ Richard A Posner, Economic Analysis of Law (Aspen Publishers, 2011) cited in Lewis Kornhauser, 'The Economic Analysis of Law' in Edward N Zalta (ed), The Stanford Encyclopedia of Philosophy (Metaphysics Research Lab, Stanford University, Fall 2017) $<$ https://plato.stanford.edu/archives/fall2017/entries/legal-econanalysis/ $>4$.

${ }^{88}$ Simon F Deakin, 'The legal theory of finance: implications for methodology and empirical research' (2013) 41 Journal of Comparative Economics 338.

${ }^{89}$ Cento Veljanovski, The Economics of Law (Institute of Economic Affairs, 2nd ed, 2006) 145.

${ }^{90}$ Richard A Posner, 'The economic approach to law' (1975) 53 Texas Law Review 757, 782 cited in Louis Kaplow and Steven Shavell, 'Economic Analysis of Law' in A J Auerbach and M Feldstein (eds), Handbook of Public Economics (Elsevier Science BV, 2002) vol 3 ch 25.

${ }^{91}$ Kaplow and Shavell (n 90) vol 3 ch 25 [7.3] 1765.
} 
That the Australian economy has not developed its innate entrepreneurial qualities into an ecosystem comparable with the US ${ }^{92}$ and Germany is in part a result of legal uncertainties and complexities. Foregone economic activity is also a function of the loss of capital quantified by empirical analysis and consequential risk aversion of Australian investors, institutional and private, from the losses resulting from an inchoate regulatory system. It is not possible for a risk seeking entrepreneurial ecosystem to grow sustainably with such a loss of capital. Hence the paucity of capital availability for Australian SMEs. These companies wither.

Some authors ${ }^{93}$ claim causality between legal origins and financial market outcomes, a primary legal distinction being common and civil law origins.

Legal protections not only facilitate diversification of financial commitments by the existing investor base, but also and in addition, must encourage small investors to put their savings in equity. This then leads to the broadening of the investor base which is associated with bigger and deeper markets. Thus law begets markets. ${ }^{94}$

Comparative law research supports this conclusion. Similarly, differing jurisdictions change market practices using methods other than legal tools to implement policy reform: 'law is hardly ever the only or even the culprit of a crisis. Conversely, legal solutions are not necessarily the most important remedy ... actual change is contingent on non-legal factors... ${ }^{95}$ The importance of behavioural economics research is understated and under-researched in Australia, where emphasis on statutory accretion serves as 'diagnostic tools for policy reform' ${ }^{96}$ without applying the insights from comparative jurisdictions. Emphasis on objective strategy based on multiple tools in Australia

\footnotetext{
${ }^{92}$ See, eg, Bernard Salt, 'What happened to the spirit of the Aussie entrepreneur?', The Weekend Australian (Sydney), 10-11 March 2018.

${ }^{93}$ Pistor (n 28) 1113.

${ }^{94}$ Ibid 1650.

${ }^{95}$ Ibid 1669.

${ }^{96}$ Ibid 1658.
} 
would serve to reduce the impact of interest group driven politicised policy recently experienced in the financial planning and superannuation sectors.

Community expectations of, and trust in what each market participant should do has often been different from what they actually do. 'Be under no illusion, there is still a trust deficit between investor and customer... ${ }^{97}$ Ambiguities lead to a false sense of security which have been sadly and damagingly misplaced. 'Lilliputian battles ... whose petty victories ... were trumpeted in the columns of their fawning acolytes in the press ${ }^{, 98}$ gave comfort that these problems were being resolved. These battles continue. Wallis inspired principles of disclosure, advice, and financial literacy, whilst commendable, have been implemented with a certain naivety leading to severe personal and nationwide economic damage.

One court likened Australia's financial services and financial products industries to Dante's Inferno. It chose vivid adjectives 'byzantine' and 'purgatorial'. ${ }^{99}$ This speaks loudly of the need for rational reform in the provision of financial products and financial services. Reform objectives must be to re-establish trust, confidence and respect, lost in several decades of often anonymous or poorly-informed financial product selling to vulnerable retail investors, despite repeated analysis and with similar conclusions from $2001 .^{100}$

The goal of reform must be clearly directed at restoring public trust, confidence, and respect. Fundamentally, this requires recognition of fiduciary obligations to investors and beneficiaries often wrongly assumed by them to exist. Directors, trustees, and those that advise them are responsible.

\footnotetext{
${ }^{97}$ Niall Coburn, 'Compliance challenges facing the financial services industry - how do I turn risk into opportunity' (Paper presented at Thomson Reuters Summit, Beijing, November 2017) 4.

${ }^{98}$ A N Wilson, Our Times (Hutchinson, 2008) 411.

${ }^{99}$ Wingecarribee Shire Council v Lehman Brothers Australia Ltd (in Liq) [2012] FCA 1028 [118] (Rares J).

${ }^{100}$ Lord Myners (n 51).
} 
Often not deliberately dishonest, sometimes 'messianic' ${ }^{101}$ but nonetheless not fit and proper in any meaningful sense.

Disclosure is not always understood by readers and has not prevented manifest conflicts of economic interest in the management of those activities. In the application of the second Wallis principle, financial advice, there is a distinction between the general law duties of skill and care and fiduciary obligation, constrained by associated contractual provisions in the relationship and the Corporations Act. Investors may be surprised to learn that in 2019 there is no statutory fiduciary duty to the client in respect of this second limb of Wallis. The assumption that fiduciary principles always apply is false. They do not, and the fact that statutory application of fiduciary principles was proposed to apply to what was sold as professional advice speaks volumes for the corrupted ethical cultures of the organisations and individuals involved. The typology 'dealer group' implies something other than professional advice. It speaks loudly of systemic deficiencies in Australia's financial culture, but a deficient statutory solution. The general law fiduciary standard is now subsumed by a statutory best interest duty. This does not apply in other jurisdictions. Hayne does not address this issue other than termination of 'grandfathered' commissions, now publicly contested.

Even before Hayne, ${ }^{102}$ large Australian financial institutions added to the unease by needing to compensate clients for advice that was contracted but not provided. Whilst this is not of itself a breach of fiduciary duty, it underscores legal uncertainty in the mind of a layperson, a financial consumer. Fiduciary duties in Australia are not directly concerned with the quality of advice, although that quality may differ depending on whether any fiduciary duty obligations are discharged or not.

\footnotetext{
${ }^{101}$ ASC v Donovan (1998) 28 ACSR 58 (Cooper J).

${ }^{102}$ Hayne (n 3).
} 
In the US, there is a similar debate, politicised as in Australia, also extending to the regulators. Retail investors (Moms and Dads) typically are exposed to brokers and, separately, investment advisers. There has been no uniform fiduciary standard for brokers and investment advisers, although there has been a best interest test. Brokers have typically earned a fee from product manufacturers and mutual funds whilst making suitable recommendations and in some cases managing client accounts, whereas investment advisers typically earn an asset based fee. The US Securities Exchange Commission (SEC) intended a uniform fiduciary standard for all retail investor retirement advice. The SEC has the regulatory power under Dodd-Frank ${ }^{103}$ but political division and continued lobbying has prevented implementation. Financial professionals who provide advice related to retirement monies must act as fiduciaries (in the US interpretation of fiduciary) and brokers who manage retirement monies must act with best interest, and similarly for non-retirement accounts where they have investment discretion or asset related fees. Fiduciary responsibilities are to be underpinned in enforceable best interest contracts. Judicial review in the US and Canada has extended fiduciary relationships 'to be used for creating new forms of civil wrong', being from an Australian perspective an 'unsatisfactory development of the law of fiduciary obligation'. ${ }^{104}$

Investors may also be interested to learn that a custodian in Australia does not necessarily have the meaning assumed by an investing layperson. There is a disconnection between public expectation and industry practice. Many people assume that the mere attribution of the custody title confers fiduciary duty and protection to an investor akin to a trustee. It does not. Deficiencies in the Australian custody sector were identified in 2003 and Australian law still does not follow international standards.

${ }^{103}$ Dodd-Frank Wall Street Reform and Consumer Protection Act of 2010 (United States) Public Law 111 203.

${ }^{104}$ Westpac Banking Corporation v The Bell Group Ltd (in liq) [No3] [2012] WASCA 157 [901] (Drummond AJA). 


\section{Community Expectations - Disconnection with the 'Twin Peaks' Model of Regulation and Supervision}

Community expectation is tempered by belief systems, behavioural norms, and financial competencies leading to systemic misunderstandings based upon 'limited ability to unravel $\operatorname{risks...}^{, 105}$

Discussion of expectation, culture, and intervention is incomplete without a wider view of the value to individual investors and the entrepreneurial economy of investors having access to various types of financial product, including MIS. Should the libertarian paternalism espoused by Cooper ${ }^{106}$ in respect of superannuation investment be copied in these other investment asset classes? If so, what is the effect on the entrepreneurial economy? At an individual level, would such policy enhance financial literacy? Probably not, since impairment of capital is one element of understanding risk. Some jurisdictions do restrict retail investor access to many types of financial product, ${ }^{107}$ a consequence being more reliance on government and less individual endeavour. However, this is not the optimal response to the systemic problems in Australia. 'Where should responsibility for citizens' longer term financial security lie?' ${ }^{108}$ Policy conflicts arise from investor realisations post-NBFE collapses where 'little active supervision is revealed, financial consumers are incredulous, angry and mistrustful' ${ }^{109}$ Disclosure assumes that 'all investors are the same'110 and make informed decisions. This is not the case, despite their having responsibility for decision

\footnotetext{
${ }^{105}$ Christine Brown, Colm Tussler and Kevin Davis, 'Managed Investment Scheme Regulation: Lessons from the Great Southern Failure' (2011) The Finsia Journal of Applied Finance 11.

${ }^{106}$ Cooper (n 53).

${ }^{107}$ Dimity Kingsford Smith, 'ASIC regulation for the investor as consumer' (2011) 29 (5) Companies and Securities Law Journal 336.

${ }^{108} \operatorname{Ibid} 353$.

${ }^{109}$ Ibid 354.

${ }^{110}$ Ibid 329.
} 
making. In Australia, there are 'limited and sparse existing programs of investor education and assistance', ${ }^{111}$ with ASIC concluding that 'investor education is worthwhile though it must be pursued in the long term in tandem with other strategies that build in the fact that retail investors are not the hard-headed decision makers often supposed. ${ }^{112}$ Implicit recognition of the importance of behavioural economics theory.

Expectations gaps between regulators and stakeholders 'resonate today, arising as they do out of legal and technical difficulties in applying a single regime to a disparate collection of investment and quasi-investment arrangements that utilise different legal forms and are used for different commercial purposes'. ${ }^{113}$ This is particularly so for unregistered MIS and those common enterprise MIS where there may be no tangible trust property, investor benefits being limited to chose in action, sometimes only exercisable through conflicted power of attorney. Desire for retribution from those aggrieved has been compounded by ASIC not choosing 'to use enforcement as a primary means of shaping MIS jurisprudence', ${ }^{114}$ although the NBFE cases do not support that proposition. More recent policy directions to address culture, director and investor education seek to facilitate its mandate by lifting ethical and educational standards across its regulated universe. If continued, these strategies are generational and rebalance ASIC as a Responsive Regulator, less reliant upon statutory compliance and more focussed on the import of fiduciary concepts.

One of the benefits of Australia's Twin Peaks model is the application of differing approaches to similar problems. A primary difference between ASIC, APRA, and the Registered Organisations Commission (ROC)) is the number and diversity of NBFE entities regulated. APRA

\footnotetext{
${ }^{111}$ Ibid 334.

${ }^{112} \operatorname{Ibid} 338$.

${ }^{113}$ Pamela Hanrahan, ‘ASIC and managed investments' (2011) 29 Companies and Securities Law Journal 297.

${ }^{114}$ Ibid 289.
} 
is more closely involved with its regulated entities through ex ante supervision than ASIC with its ex post market conduct model, until recently largely adversarial, relying on court based enforcement. ${ }^{115}$ The former makes for relational regulation based upon earlier interventions. ASIC's recent focus on culture and education makes for a more relational environment: Responsive Regulation. This form of regulation 'champions internalisation ... it is usually impossible for society to organise its resources so that rewards and punishments await every act of compliance or non-compliance'. ${ }^{116}$ The objective is to achieve compliance by internal means, sometimes underscored by means of enforceable undertakings, ${ }^{117}$ commonly used in Australian financial services and financial products regulation.

Active involvement (common in prudentially regulated entities) can diffuse required behaviours into NBFE governance and at many levels of the entity, not just its compliance management. This would require additional skills sets in ASIC to embrace microeconomic analysis and its inclusion in disclosure documents. It would be an ex ante extension of present licencing powers to prevent, restore and rehabilitate. It balances its ex post adversarial powers. 'This would mean a cultural change in firms and the board and senior management working to change the acceptance of regulators in firms'. ${ }^{118}$ Such policy does not have the 'public drama of prosecutions'. ${ }^{119}$ Lack of public confidence has resulted in ASIC's review of its Australian

\footnotetext{
${ }^{115}$ See, eg, Helen Louise Bird et al, ASIC Enforcement Patterns (Centre for Corporate Law and Securities Regulation, University of Melbourne Law School, 2003).

${ }^{116}$ Dimity Kingsford Smith, 'A harder nut to crack? Responsive Regulation in the financial services sector' (2011) 44 (3) University of British Columbia Law Review 702.

${ }^{117}$ Ibid 704.

${ }^{118}$ Ibid 738.

${ }^{119}$ Ibid 741.
} 
Financial Services Licence (AFSL) and Credit Licence banning powers concurrently with the introduction of the Banking Executive Accountability Regime (BEAR) for ADIs. ${ }^{120}$

${ }^{120}$ Australian Government The Treasury, 'ASIC's power to ban senior officials in the finance sector' (ASIC Enforcement Review Position and Consultation Paper, 6 September 2017) 1. 


\section{Community Expectations - Gap with Market Practices in the Governance of Financial Products and Services}

A consumer of financial products and services is often vulnerable because of lack of experience and expertise in investment. This vulnerability should enliven fiduciary obligations. The important characteristic of a fiduciary relationship is one of trust and confidence, the fiduciary acting for or on behalf of the interests of another. ${ }^{121}$ The fiduciary power must be exercised in the interests of the investor or client with no unauthorised profit or conflict accruing to the fiduciary. Fiduciary relationships should occur at every point in the investment chain where there is discretion or advice. Economic interest of the ultimate consumer should be paramount. The beneficiary must have confidence in the agent even if that agent is several steps removed. Trust in the investment chain is only as 'strong as the trust in the weakest link of that investment chain'. ${ }^{122}$ Defining status-based fiduciaries is fundamental.

Directors are often placed in situations of conflict of interest and conflict of economic objective by virtue of the architecture of their organisations. Considerable systemic risk is generated by related party transactions and consequential conflicts of interests and objectives. These occur in a complex investment chain controlled by multiple intermediaries and is incompatible with the concept of a fiduciary having stewardship of client property. Related party transactions are common in NBFEs.

Present financial advice regulation is directed at prioritisation rather than prohibition of conflicted dealings. For financial products subject to trust general law or its statutory

${ }^{121}$ Australian Securities and Investments Commission v Citigroup Global Markets Australia Pty Ltd (No 4) [2007] FCA 963.

122 John Kay, The Kay Review of UK Equity Markets and Long Term Decisions Making (Final Report, July 2012) 65. 
implementation in the SIS Act, there is prohibition, although not exclusively. ${ }^{123}$ Murray ${ }^{124}$ noted that there is increasing industry consolidation and vertical integration. This results in increasing number of related parties and increased potential for conflicts of interest. ${ }^{125}$ ASIC's report particularly relates to financial product manufacturing and distribution, outsourcing, fiduciary obligations, remuneration, ownership interests, and use of information. These and other conflicts also arise in prudentially regulated NBFEs. ASIC specifically suggests 'better training for directors', ${ }^{126}$ the 'engagement of separate external legal advisers' in conflicts of a fiduciary nature, ${ }^{127}$ and cultural responses to conflicts management ${ }^{128}$ to disrupt 'systemic conduct that is driven by poor culture'. ${ }^{129}$

But, conflicts and the taking of profits have often arisen permitted by the subsuming of fiduciary principles by contract and statute. Australian Softwood Forests is an earlier, but not unusual example: 'The schemes are generally designed so that all the investors ever receive are the pieces of paper constituting the agreements ... promoters design increasingly more sophisticated schemes in attempts to circumvent the laws'. ${ }^{130}$

Directors of companies and trustees have differing fiduciary responsibilities. 'As a general rule, all powers vested in directors under the company's articles are fiduciary powers to be

\footnotetext{
${ }^{123}$ APRA, Conflicts of interest (at July 2013) Prudential Standard SPS 521.

${ }^{124}$ Australian Government The Treasury, Financial System Final Report (2014).

${ }^{125}$ ASIC, Culture, conduct and conflicts of interest in vertically integrated businesses in the fundmanagement industry (Report 474, March 2016).

${ }^{126}$ Ibid 106.

${ }^{127}$ Ibid 123.

${ }^{128}$ Ibid 168.

${ }^{129}$ Ibid 28.

${ }^{130}$ Australian Softwood Forests Pty Ltd v A-G (NSW); Ex Rel Corporate Affairs Commission [1981] HCA 49 [37] (Murphy J).
} 
exercised in the interests of the company'. ${ }^{131}$ Fiduciary responsibilities are also set out in statute, specifically the Corporations Act and SIS Act, but not in the Fair Work (Registered Organisations) Amendment Act where general law fiduciary duty traditionally applied in the context of dependence.

The director of a trustee and a director of another entity associated with the asset can concurrently be the same person managing the same underlying assets. This is one of many conundrums leading to uncertainty in NBFE governance. Harmonisation of fiduciary duty across the governance of the NBFE sector is required to eliminate inconsistency in the law. Like the cleansing effects of economic recession, a statutory prohibition on conflicts of interest is required to eliminate ambiguity, uncertainty, and redevelop lost confidence in a market based regulatory system. Statutory interventions prioritise not prohibit. This is dangerous for beneficiary, client, and trustee director alike. They do not resolve the cultural problems identified by Heydon, opining that poor culture drives poor conduct. Nor Hayne's concern for the confluence of law and morality.

There is no controversy over the existence and scope of a fiduciary's fundamental proscriptive duties, although there may be $[\text { is }]^{132}$ over the precise nature and extent of them. ${ }^{133}$ There is 'no standard test to be applied to determine whether the parties are within a fiduciary relationship'. ${ }^{134}$ It depends on the facts and the context, including 'contractual arrangements'. ${ }^{135}$ The essence of the fiduciary relationship is the exercise of power by one party for the benefit of another, the principles being: 'unless there are some special circumstances in the relationship, the

${ }^{131}$ Westpac Banking Corporation v The Bell Group Ltd (in liq) [No3] [2012] WASCA 157 [1949] (Drummond) AJA.

${ }^{132}$ Commonwealth, Royal Commission into Trade Union Governance and Corruption (Interim Report, December 2014), ch 4 s 2.5, 42 (Commissioner Heydon).

${ }^{133}$ Ibid; See also, Westpac Banking Corporation v Bell Group Ltd (in liq) (No 3) [2012] WASC 15744 (Owen J).

${ }^{134}$ Westpac Banking Corporation v The Bell Group Ltd (in liq) (No3) [2012] WASCA 157 [836] (Lee AJA).

${ }^{135}$ Hospital Products Ltd v United States Surgical Corporation [1984] HCA 64 [102] (Gibbs CJ, Mason J). 
duties that equity demands from the fiduciary will be limited to what he described as the "two core obligations' relating to unauthorised benefits and conflicts of interest'. ${ }^{136}$

The determining factor is 'the well-established rule that the scope of the fiduciary duties in a particular relationship will vary and is to be determined according to the nature of the relationship and the facts of the particular case'. ${ }^{137}$

The need to analyse each discrete case for fiduciary obligation strikes at the heart of the systemic cause of the chasm between client or investor expectations and market practices in financial services advice or financial products selling. There have been misplaced expectations by investors in NBFE financial products and services transactions that there is a relationship based in fiduciary principles. Part of the mismatch in expectations has been poor financial literacy and misunderstanding of the law (including fiduciary law), but part is innate trust based on fiduciary principles assumed by investors in professional persons with whom they deal.

${ }^{136}$ Westpac Banking Corporation v The Bell Group Ltd (in liq) (No3) [2012] WASCA 157 [1944] (Drummond AJA).

${ }^{137}$ Ibid [1970]. 


\section{Statutes at Variance - Uncertainty in Directors and Trustee Duties}

NBFE directors are confronted by overlapping and confusing trust law, general law and statutory provisions. They can rarely be certain of their duties. This confusion extends to those who invest in their entities, their legal advisers and to those determining whether appointees meet fit and proper criteria. ${ }^{138}$ 'A legal vacuum has been created by the evolution of the trust as a vehicle for large scale enterprise, and the apparent tardiness of Australian legislatures to accommodate this development'. 139 '[T]rustee-directors should not have to collate rules from multiple sources in order to understand their core duties'. ${ }^{140}$

There are differing standards applying to director duties under the Fair Work Act (Registered Organisations) Amendment Act, Corporations Act, and SIS Act. Many NBFEs are multifunction financial institutions of considerable size subject to regulation by or the influence of each of these statutes.

Like Esau and Jacob, 'vying for power even in their mother's womb', ${ }^{141}$ the jurisdictional differences in history, culture, and desire for specific types of governance lead to a zero sum game. Whilst there may be some tactical reform, these struggles for power and influence have not necessarily improved conditions for the people they purport to protect. 'Appointees [to the Fair Work Commission] are regularly described as "union friendly" or "employer friendly" giving rise to 'claims of bias'. ${ }^{142}$ Neither is there unanimity of professional opinion as to the solutions. ${ }^{143}$ The

\footnotetext{
${ }^{138}$ John Farrar and Pamela Hanrahan, Corporate Governance (Reed International - LexisNexis Butterworths, $1^{\text {st }}$ ed, 2017) [30.15].

${ }^{139}$ Nuncio D’Angelo, Commercial Trusts (LexisNexis Butterworths Australia, 2014) 119 [3.23].

${ }^{140}$ Cooper (n 53) pt 2 ch 2, 46.

${ }^{141}$ Wilson (n 98) 410.

${ }^{142}$ Heydon (n 65) ch 2, 39.

${ }^{143}$ Michael Chaaya, Corrs Chambers Westgarth, Australia: Stronger Super: a new dawn for trustee governance (Mondaq Ltd, 2013).
} 
Corporations Act impacts on 'ASIC's ability both to respond to the recommendations made in this report, and on its ongoing and future ability to fulfil its mandate efficiently and effectively'. ${ }^{144}$ It cites 'legislative and regulatory complexity ... and in particular the application of the Corporations Act' ${ }^{145}$ From 1981-2018, its word count has increased from 257419 to $729056 .{ }^{146}$ These concerns are 'shared by numerous members of the judiciary who note that 'every significant amendment to the corporations legislation ... has added substantially to complexity' such that it is now “inescapably complex"” 147 'Treacherous', 'incomprehensible', 'as clear as mud', are other judicial adjectives. ${ }^{148}$ Cooper has previously proposed a rewrite of the SIS Act citing complexity grounds. ${ }^{149}$ To add to the confusion, four recent reform proposals have failed or struggled to gain necessary political support, ${ }^{150}$ with compromised reform to the governance of registered organisations finally enacted in December 2016. ${ }^{151}$

${ }^{144}$ Karen Chester, Mark Gray, and David Galbally, 'Fit for the future: A capability review of the Australian Securities and Investments Commission' (Australian Government Treasury Report, December 2015) 133.

145 Ibid.

${ }^{146} 2018$ word count in c 3000 pages, excluding 250 Regulatory Guides, multiple class order exemptions, and 20,000 s 1322 exemptions. For a more detailed review, see especially Chia and Ramsay, above n 42, 389 who report word count data to 2015 citing $<$ http://www.comlaw.gov.au/Series/C2004A00818>. This data for 2018 has been manually compiled from this source by computing the word count in six volumes of the Corporations Act. It excludes recent addition of chapters $8 \mathrm{~A}$ and $8 \mathrm{~B}$.

${ }^{147}$ Chester, Gray and Galbally (n 144) 134 quoting Michael Kirby writing extra-curially in R Hinchy and P McDermott, Company Law (Pearson Education Australia, 2006).

${ }^{148}$ Chia and Ramsay (n 42) 391-2.

${ }^{149}$ Cooper (n 53) 327.

${ }^{150}$ Superannuation Legislation Amendment (Trustee Governance) Bill 2015 (Cth); Fair Work (Registered Organisations) Bill 2013 (Cth); Fair Work (Registered Organisations) Amendment Bill 2014 (Cth); Fair Work (Registered Organisations) Amendment Bill [No 2] 2014 (Cth).

${ }^{151}$ Fair Work (Registered Organisations) Amendment Act 2016 (Cth). 
These sentiments are not new. 'There is a point where company law ends and trust law takes over', ${ }^{152}$ not a distinction recognised by many directors. Many NBFEs, particularly MIS and superannuation entities, are trusts with a corporate trustee. Trust structures were not originally intended to be used for risk seeking commercial business activities, or to be leveraged with debt to fund those activities. An MIS is a trust. Trust law applies. ${ }^{153}$ These distinctions apply particularly to unregistered and/or insolvent MIS, transfers of property by a fiduciary, superannuation entities, asset allocation decisions or cases involving Canadian and US participants.

For directors of complex NBFEs, these legal uncertainties, overlaid with beneficiary and investor expectations of value outcomes rather than rights make for difficult territory. In Sino Iron, ' $[\mathrm{t}] \mathrm{o}$ require that a defendant must actually appreciate that the relevant facts constitute a trust in law would favour the legally ignorant over the legally aware, when the facts and knowledge are otherwise identical'. ${ }^{154}$

In Imobilari v Opes Prime, 'Again, one might justifiably question whether even the trained legal mind is capable of making such fine distinctions. ${ }^{155}$ '[T] here is a clear twin policy imperative for pursuing legislative reform of the Corporations [Act] law - to both simplify and contemporise the law'. 156

Since trusts and MIS are not legal entities, they cannot become insolvent. There has not been a body of law developed to administer situations where the assets of the trust are not sufficient to meet the liabilities required to be discharged by the trustee or the RE, themselves normally

\footnotetext{
${ }^{152}$ Nuncio D’Angelo, 'The trust as a surrogate company' (2014) 8 Journal of Equity 306.

${ }^{153}$ Corporations Act 2001 (Cth) s 601FC(2).

${ }^{154}$ Sino Iron Pty Ltd v Palmer (No 3) [2015] QSC 94 [144] (Jackson J).

${ }^{155}$ Imobilari Pty Ltd v Opes Prime Stockbroking Limited [2008] FCA 1920 [29] (Finkelstein J).

${ }^{156}$ Chester, Gray and Galbally (n 144) 135.
} 
contractually indemnified from those assets. Consequently, directors and trustees need to understand multiple and inconsistent statutory provisions, general law, and equity.

The insolvency provisions of the Corporations Act relating to formal administration, receivership, and liquidation do not apply to trusts and MIS. Registered MIS have some limited statutory provision, ${ }^{157}$ not applying to unregistered MIS. The trustee or RE may become insolvent whilst it administers entities where their underlying assets are insufficient to meet creditor liabilities. There are also cases where the trustee or RE also administer trusts and MIS which are commercially sound, although the trustee or RE is not. Further complications arise where leverage, sometimes multiple layers of it, is part of the capital structure. For trusts and MIS which are listed on the ASX of other securities exchanges, the listing rules apply to the trust or the MIS, but not to the trustee or RE and their directors.

Personal liability in commercial trusts is also different in the US, being statute limited for investors, ${ }^{158}$ by trust law for trustees ${ }^{159}$, and for investors in Canadian trusts by provincial statute. ${ }^{160}$ In Singapore, its Business Trust Act ${ }^{161}$ eliminates personal liability for unitholders whilst extending personal fiduciary liability of trustee directors to them.

${ }^{157}$ Corporations Act 2001 (Cth) Part 5C.9.

158 The Uniform Statutory Trust Entity Act 2009 (United States) § 304 cited in D’Angelo, Commercial Trusts, above n 156, 193 [4.105] codifies and synchronises state trust law through the Uniform Trust Code 2000 (amended 2005) to regulate and clarify the use of commercial trusts in mutual funds and structured finance. See generally John H Langbein, 'Why Did Trust Law Become Statute Law in the United States?' (Faculty Scholarship Series Paper 496, 2007) <http://digital commons.law.yale.edu/fss papers/496>.

${ }^{159}$ D’Angelo, Commercial Trusts (n 144) 193 [4.106].

${ }^{160}$ Trusts Beneficiaries Liability Act 2004 (Ontario) s 1 cited in ibid 148 [395].

${ }^{161}$ Business Trust Act (Singapore, Act 30 of 2004) Cap 31A s 32 cited in D’Angelo, Commercial Trusts (n 144) 149 [3.98]. This statute regulates 'active trusts' being functionally similar to Australian unregistered MIS. 


\section{The Ascent to Uncertainty}

There is no commonality of strategy and no policy consistency from the competing political parties. Empirical research demonstrates that ideological orientation influences regulatory policy. ${ }^{162}$ There is a moral hazard in that investor expectations may assume that the regulatory system is designed as a zero failure policy. It is not. There needs to be realistic community expectations as to what regulation and supervision can achieve in practice.

Despite Australia's elaborate regulatory architecture, which of itself contributed to these community expectations, Australia has a regulatory malaise in the NBFE sector which the inconsistencies of, and conflicts of interest in, public policy are ill-equipped to remedy. The current system is complex and ineffective. ${ }^{163}$ The report into ASIC itself demonstrates clearly that there are 'broad systemic problems in the financial advice industry' which may recur. ${ }^{164}$

It is manifestly important that Australia subscribe to international regulatory standards and that its own funds management products and services can be readily available in other jurisdictions. As with financial literacy, this should be seen as a productivity measure. Financial products harmonisation with international standards could assist Australia develop commonality of strategy and consistency in public policy. It would also remove some of its systemic deficiencies in the regulation of financial products and services and improve access to capital for companies, another productivity measure.

\footnotetext{
${ }^{162}$ Laurenz Ennser-Jedenastik, 'Do parties matter in delegation? Partisan preferences and the creation of regulatory agencies in Europe' (2016) 10(3) Regulation and Governance 193.

${ }^{163}$ Tom Valentine, 'The Regulation of Investments' (2010) 27(3) Economic Papers: A journal of applied economics and policy 273.

${ }^{164}$ Australian Government, The Senate Economics Reference Committee, Performance of the Australian Securities and Investments Commission (June 2014) 377.
} 
Whether there should be a single prudential regulator for the entire financial system was addressed in 1996, ${ }^{165}$ and 2009, ${ }^{166}$ and by Hayne. Prima facie, there may be argument for combination of the regulatory functions into one entity since many NBFEs are regulated by both ASIC, APRA, ATO, ROC and the Australian Competition and Consumer Commission (ACCC). This argument does not survive insightful scrutiny. ${ }^{167}$ Hayne agrees, recommending increased periodic reviews (and a Capability Review of APRA). All five regulators, in the same jurisdiction, are required to develop policy responses and manage problematic issues which have some commonality. Their differing powers and cultures result in differing responses. This is a useful outcome and leads to a more diverse regulatory response based on learning and differing knowledge bases which can be shared. That is not to say that prudential regulation cannot be applied by ASIC to the managed funds industry, only that it has a different result to that applied by APRA.

Johnson ${ }^{168}$ is of the view that the separation of responsibilities has served Australia well. Cooper not favouring a single regulator approach — and without explicitly criticising Wallis, is intent on moving away from its paradigm under the guise of improving outcomes for members on the basis that 'members are not in a position to drive changes themselves'; ${ }^{169}$ ie Wallis' third limb of financial literacy has not worked in practice for superannuation NBFEs. Investor financial literacy is stated to be 'an important long term goal, but a compulsory superannuation system cannot depend on all its participants having the skills necessary'. ${ }^{170}$ Cooper is of the view that

\footnotetext{
${ }^{165}$ Phil Hanratty, 'The Wallis Report on the Australian Financial System: Summary and Critique' (Research Paper No 16, Department of the Parliamentary Library Information and Research Services, 1997) 24. ${ }^{166}$ Mark Johnson, 'Australia as a Regional Financial Centre' (Financial Centre Forum Report, January 2010) 143.

${ }^{167}$ Valentine (n 163) 273.

${ }^{168}$ Mark Johnson, 'Australia as a Financial Centre: Building on our Strengths' (Australian Financial Centre Forum Report, November 2009).

${ }^{169}$ Cooper (n 53) ch 10, 309.

${ }^{170}$ Ibid ch 1, 4.
} 
'disclosure is a necessary, but not a sufficient, condition for ensuring that member interests prevail'. ${ }^{171}$ This demonstrates a lack of confidence in Wallis' first limb. The remaining limb, advice, has been addressed elsewhere, but trustees are likely to have greatly extended obligations to members in the provision of advice to those members.

Whilst Cooper does not envisage APRA's role extending to intervening directly in trustee decisions, trustee directors are now subject to significantly enhanced statutory liability for beneficiary outcomes. This has major implications for director appointments, remuneration, and insurance. The tradition of general law principles based regulation rather than prescriptive statutory regulation has led to differing interpretations by directors, the regulators, and the courts.

There is further tension between regulation and supervision. ${ }^{172}$ The Wallis posture of regulation based on intervention proportionate to the problem is different from direct oversight of financial institutions. Superannuation entities are subject to ex ante supervision, often active. MIS and other NBFEs are subject to ex post conduct regulation. Harmonisation needs to occur with ASIC moving to an ex ante supervisory agency, and applying prudential supervision to registered MIS and other NBFEs. This would improve ASIC's ability to meet community expectation without destroying the three central tenets of Wallis: disclosure, advice and investor empowerment. ASIC would be able to focus on necessary reform of the MIS sector envisaged by the Corporations and Markets Advisory Committee (CAMAC), ${ }^{173}$ at least in part. This includes elimination of the poacher/gamekeeper problem and proper prudential capital arrangements for MIS. It would also diminish the consequences of damaging ex post regulatory action on third parties since the NBFE market would become accustomed to a culture of supervision, different from regulation. Restoring

\footnotetext{
${ }^{171}$ Ibid.

172 John Laker, 'Enhancing the competitiveness of financial services-lessons learnt and opportunities for improvement' (Speech delivered at the International Financial Services Association Annual Conference, 6 August 2009).

${ }^{173}$ D'Angelo 'The CAMAC Report' (n 72) 256.
} 
the prescribed interest dual party system does not of itself provide better investor protection, although it would considerably widen the opportunity for remedy in the absence of MIS prudential regulation.

For the market to hold directors to account, the third limb, investor empowerment, as Cooper acknowledges, has limited success, and requires new strategy and common statutory interventions. Lifting financial literacy standards in Australia should be seen as a productivity policy and responsibility for its implementation given to an agency other than ASIC. Poor financial literacy is a common theme in the cases.

The alternative to investor empowerment is libertarian paternalism which has its own dangers. This philosophy of libertarian paternalism espoused by Cooper and enacted in a compulsory contributory superannuation system reform supposedly to 'maximise outcomes for passive superannuation fund members whilst allowing the actively engaged to select their own direction' ${ }^{174}$ Echoes of paternalism are to be found in MIS. For instance, the proposed liability of financial product manufacturers (normally fund managers) for the suitability of the product for specific investors is a preferred reform proposed by ASIC and includes a best interests duty and prohibitions or limitations on financial product availability. The result would be to extend product liability to the product originator and require them to have the infrastructure as if they were providing a potential investor with financial advice.

This philosophy is used to justify a greater scope for government regulation and involvement, and is manipulated in the governance of industry superannuation funds by the application of the Fair Work Act to superannuation contributions. Presently, the superannuation sector is largely outsourced to the private sector, placing enormous economic power in the hands of the trustees.

\footnotetext{
${ }^{174}$ Cooper (n 53) 9, 17.
} 
Without policy clarity in respect of the objectives of superannuation funds identified by Murray, ${ }^{175}$ it is but a short step to their application for economic development objectives, especially in a constrained fiscal environment. By 2035, the Australian superannuation sector is expected to have AUD6.1 trillion under management, ${ }^{176}$ of which approximately $50 \%$ would be in default funds. These economic development objectives may include infrastructure investment, venture capital, government securities, and other sectors which are adept at influencing the political milieu. There are already examples in the industry superannuation fund sector, and including where there are related parties. "Investment strategy" is not anywhere defined in the SIS Act ... there is little guidance provided as to what constitutes an investment strategy nor of the level of detail required'. ${ }^{177}$ Peer pressure, whether it be from similar funds, government policy objectives, or community views, can easily lead to trustee diversion 'from their single minded pursuit of members' interests by the clamour... ${ }^{178}$ What may constitute best interest in the pursuit of peer performance in other jurisdictions cannot necessarily be translated to Australia.

It is a short step to part nationalisation of some of these funds, particularly default funds, with the management subsumed into government agencies, ${ }^{179}$ already publicly suggested. This may suit the proponents of libertarian paternalism, and there are obvious arguments to support such a strategy. ${ }^{180}$ 'A public sector solution is likely to be most efficient, provided the annuitisation is

\footnotetext{
${ }^{175}$ Donald, 'Regulating for fiduciary qualities of conduct' (n 33).

${ }^{176}$ Cooper (n 53) pt 1 app C: Treasury assumptions for modelling 72. Nominal 2018 equivalent AUD3.2 trillion.

${ }^{177}$ M Scott Donald, 'Prudence under pressure' (2010) 4 Journal of Equity 44.

178 Ibid.

${ }^{179}$ For example, the Singapore Central Provident Fund, Future Fund, Queensland Investment Corporation.

${ }^{180}$ Michael Sherris and John Evans, 'Longevity Management issues for Australia's future tax system' (Australian School of Business, University of New South Wales, August 2009) 15.
} 
compulsory'. ${ }^{181}$ Such a policy would do little to meet the Wallis objectives of investor empowerment.

Murray $^{182}$ supports the present regulatory architecture. Murray expresses concern about political intervention and makes the point that governments have an obligation to act in the long term national interest rather than using the financial system for short-term political gain. Policy stability and lack of clarity as to objectives are key findings in Murray since they can lead to political influences and the corruption of the system. Murray has sounded the warning bell. The Murray approach is for tactical incremental reform provided these basic strategic issues have been addressed. Whilst he 'highlights [Australia's] reliance on imported capital ... and that unfair consumer outcomes remain prevalent', ${ }^{183}$ there was no analysis of the underlying causes. These include the incidence of malfeasance arising from injudicious incentives based on prioritisation rather than prohibition, often with related parties.

${ }^{181}$ Ibid 38.

${ }^{182}$ Murray (n 64).

${ }^{183}$ Jeffrey Carmichael, 'Report tinkering doesn't fix incentives problem', Australian Financial Review (Sydney), 15 December 2014. 


\section{Culture and 'Taint'}

Heydon ${ }^{184}$ explored the interface between the financial system and registered organisations. He identifies different standards for their directors and officers. Malfeasance in registered organisations is of importance to the financial system given their influence over it directly and through ASX shareholdings held by their managed funds. Australia is known around the world as having the fourth largest pool of superannuation savings, and given their projected growth, identifying and removing systemic deficiencies is of national importance. Heydon ${ }^{185}$ is insightful and provides plentiful evidence to support the hypothesis of systemic and cyclical malfeasance. It also identifies two of the primary causes: deficiencies in regulation aided by an 'unhealthy culture'.

Statutory intervention into rectifying deficiencies in culture is not restricted to registered organisations. 'Poor cultures, unsustainable business models, conflicted [financial product] distribution, and conflicts of interest ${ }^{186}$ are sought to be eliminated by extending criminal sanctions to directors and officers. The thesis that poor culture drives poor conduct is of itself an admission that lack of effective enforcement of fiduciary obligations requires criminal remedies similar to those that presently exist in the Criminal Code. ${ }^{187}$ Whilst not deviating from its ex post posture to the extent of SIS Act supervision — 'we, as the regulator, won’t be looking over everyone's shoulder to test their culture. We won't dictate how a business is run', ${ }^{188}$ nonetheless significantly extends the responsibilities of directors and officers. Specifically, further extension of director's

${ }^{184}$ Commonwealth, Royal Commission into Trade Union Governance and Corruption (Interim Report, December 2014) (Commissioner Heydon).

${ }^{185}$ Heydon (n 65).

${ }^{186}$ Greg Tanzer, 'The importance of culture to improving conduct within the financial industry' (Speech delivered at the Thomson Reuters' Third Australian Regulatory Summit, Sydney, 27 May 2015).

${ }^{187}$ Criminal Code Act 1995 (Cth) pt 2.5.

${ }^{188}$ Greg Medcraft, 'Corporate culture and corporate regulation' (Speech delivered at the Law Council of Australia Seminar, Melbourne, 20 November 2015). 
civil and criminal liability to financial services and products regulation in the Corporations Act. ${ }^{189}$ Extension of liability to subjective, ill-defined criteria would further add to uncertainty, with an additional best interest duty to customers, and further accessorial liability for market outcomes risks. It contradicts previous reform, ${ }^{190}$ and legal compliance with subjective opinion would be problematic. ${ }^{191}$ It is further evidence of statutory intervention into fiduciary principles without elimination of the reasons for this intervention. A necessary policy objective, but consistently wrong solution.

${ }^{189}$ Corporations Act 2001 (Cth) ch 7.

${ }^{190}$ Personal Liability for Corporate Fault Reform Act 2012 (Cth).

${ }^{191}$ John HC Colvin and James Argent, 'Corporate and personal liability for culture in corporations' (2016) 34 Companies and Securities Law Journal 30, 39. 


\section{To... the Real Hayne - the End of the Beginning}

Publicly reported disappointment with Hayne's 76 Recommendations ${ }^{192}$ misses the point. His essential points are simplification of the law, reform of Australian approaches to conflicts of interest and duty, effectiveness of regulators, and improvements in leadership, governance and culture to meet community expectations of the behaviour of market participants. All of these are worthy objectives, not achieved by the specific recommendations alone.

Hayne's strategic reform is not explicit in a recommendation — it occurs in the text. ${ }^{193}$ This is the need to simplify the law and implement its intent. He notes: 'because the law is now spread over so many different Acts and is as complex as it is ... the very size of the task shows why it must be tackled'. ${ }^{194}$ Further, 'lobbying ... has been a significant contributor to the current state of the law'. ${ }^{195}$ Hayne and Heydon both point to the need to eliminate lobbyist induced politically inspired carve-outs from the law, Heydon specifically referring to Workers Entitlement Funds, being exempted MIS.

Hayne concludes: 'the overall task is ... much wider. It will require examination of how the existing laws fit together and identification of the various policies given effect by the law's various provisions. Only once this detailed work is done can decisions be made about how those policies can be given better and simpler legislative effect'. ${ }^{196}$ Importantly: 'the recommendations I have made cannot wait for that larger task to begin, let alone end'. ${ }^{197}$ Much of that framework has been done. ${ }^{198}$ Hayne wants an 'integrated solution' linking law and morality, noting that 'Regulatory

\footnotetext{
${ }^{192}$ Hayne (n 65).

${ }^{193}$ Ibid vol 1, 494-496.

${ }^{194}$ Ibid 495.

${ }^{195}$ Ibid.

${ }^{196}$ Ibid 496.

${ }^{197}$ Ibid.

${ }^{198}$ Millhouse (n 49).
} 
gaming occurs when gaps open, an inevitable consequence of piecemeal change'. This is Hayne's real message.

What we presently have due to time and constraints implicit in the Letters Patent is more piecemeal tactical change, pleasing few, and without rectification of the underlying systemic causes. Management, not excision or cure. Many of Hayne's recommendations are tactical and should be seen as a pathway to further widespread reform of the law. Specifically, with the exception of superannuation corporate trustees (but not their directors) he does not address the systemic problem of conflicts of interest and duty arising from related party transactions and other forms of value shifting. This has disappointed those opposed to 'vertical integration' business models. Reform of corporate trustee duty does however, open the way to dismantling of some conflicted business models. Similarly, he opens the way for repeal of the 'safe harbour' provisions in financial advice. ${ }^{199}$ Repeal would harmonise Australian law with comparable jurisdictions. He does not propose individual licensing, a necessary precondition for a status based fiduciary, and one of the reasons for the advent of so-called 'dealer groups'. This is an omission in quality assuring the investment chain.

If the predictive veracity of this author's empirical analysis is correct, ${ }^{200}$ then the media reporting of egregious behaviour uncovered by Hayne, Heydon and the Productivity Commission should give great cause for concern. Reporting indicates that there is substantial contingent risk in superannuation and non-superannuation NBFEs. ${ }^{201}$ These cyclical manifestations have deep systemic causes.

As Hayne notes,

\footnotetext{
${ }^{199}$ Corporations Act s 961B(2).

${ }^{200}$ Millhouse (n 49) ch 3 s 3.9.

${ }^{201}$ Ibid ch 1 s 1.2.
} 
given the existing breadth and complexity of the regulation of the financial services industry, adding any new layer of law or regulation will add a new layer of compliance cost and complexity. $[\ldots][\mathrm{T}]$ here is every chance that adding a new layer of law and regulation would only serve to distract attention from the very simple ideas that must inform the conduct of financial services entities. ${ }^{202}[\ldots]$ These ideas are very simple. Their simplicity points firmly towards a need to simplify the existing law [...] in the blizzard of [statutory] provisions, it is too easy to lose sight of those simple ideas that must inform the conduct of financial services entities. $^{203}$

The calls for this Royal Commission stemmed from 2014. ${ }^{204}$ Much of the case study material was old news. ${ }^{205}$ Its mandate should be extended to all NBFEs. Hayne distinguishes between 'ticking boxes' and '[w]hat is the right thing to do?'206 The 'right thing' meets community expectations of fiduciary obligation in the investment chain.

The Productivity Commission largely supports Hayne, covering some familiar ground. It is mandated to improve competition in financial services and products provision as a disciplinary policy tool to improve consumer outcomes, acknowledging the need to balance financial stability and competition. It also recognises the practical limits of disclosure regulation, limited financial literacy competencies, recognising that behavioural economics provides important insights into policy formulation. ${ }^{207}$ These practical limitations are exacerbated by conflicts of interest,

\footnotetext{
${ }^{202}$ Hayne's 'simple ideas' are to: '[o]bey the law. Do not mislead or deceive. Be fair. Provide services that are fit for purpose. Deliver services with reasonable care and skill. When acting for another, act in the best interests of that other.'

${ }^{203}$ Heydon (n 3) vol 1290.

${ }^{204}$ Senate Economics Reference Committee, Parliament of Australia, Performance of the Australian

Securities and Investments Commission (June 2014).

${ }^{205}$ Millhouse (n 49) ch 2 s 5.1.

${ }^{206}$ Hayne (n 3) vol 1290.

${ }^{207}$ Australian Government Productivity Commission, Competition in the Australian Financial System (Draft Report, January 2018) ch 2, 85; pt 111, 352-356.
} 
particularly in vertically integrated businesses, proposing a 'legal duty of care'. ${ }^{208}$ Canadian and German models thus become both relevant and insightful.

That proposed duty includes design of a $21^{\text {st }}$ century disclosure regime ${ }^{209}$ where 'consumers resort to making decisions based on trust' ${ }^{210}$ For the Productivity Commission to achieve this policy objective, fiduciary obligation to quality assure the investment chain is an essential and inviolable precondition.

This is consistent with the need for a competition advocate. Competition should be seen as part of the overall thematic reform program, not separate from it. 'For ASIC to act as a champion of financial system competition would require a clear change ... and a change in its regulatory culture'. ${ }^{211}$ Until Hayne, there has been no 'framework or a process for effective external review of the performance of its [Australian government] financial regulators'. ${ }^{212}$ This was also proposed by Murray, ${ }^{213}$ who recommended updating the Statements of Expectations of ASIC and APRA.

Mandate extension without necessary reform is another Australian example of the 'poacher being the gamekeeper'. The ASIC Capability Review also identified deficiencies in its strategic abilities. These extend 'towards advancing consumer's interest in financial products ... That it has not already done so is of concern'. ${ }^{214}$ On Hayne's recommendation, ${ }^{215}$ a Capability Review of APRA only commenced in 2019.

\footnotetext{
${ }^{208}$ Ibid ch 8, 227.

${ }^{209}$ Ibid pt 111, 347, 366.

${ }^{210}$ Ibid pt 111, 355 .

${ }^{211}$ Ibid pt 4, 418.

${ }^{212}$ Ibid s 15.2, 424.

${ }^{213}$ Ibid s 17.2, 479. Murray proposed the establishment of a Financial Regulator Assessment Board. The Productivity Commission argue that there is "no compelling case for a "regulator to regulate the regulators"'. See Ibid 480.

${ }^{214}$ Ibid 24.

${ }^{215}$ Hayne (n 3) vol 1 rec 6.13.
} 
It is unfortunate that the Productivity Commission analysis of best interest obligations of financial advisers under the FoFA regime is incomplete. ${ }^{216}$ An uninformed reader might assume this is a statement of the law, which would be incorrect. Similarly, whilst a useful analysis of investor typology, there are no clear proposals for reform. ${ }^{217}$ It is equally unfortunate to propose extending ASIC's mandate without an agreed plan to reform it. For ASIC to adopt a supervisory proactive posture will require its substantive reform. The Commission merely proposes further examination. ${ }^{218}$ Neither does it address some systemic deficiencies in Australia law, particularly the role of fiduciary law and the modernisation of trust law to accommodate the need for trustees to apply portfolio theory in their investment decisions.

\section{W[h]ither Australia? \\ Four Themes in Law Reform}

Australian public policy is at a cross-roads. 2019 marks a seminal point in the financial reform period which commenced in 1981. There is a considerable risk that the egregious behaviour examined in the Hayne Royal Commission will result in more statutory intervention, a less entrepreneurial economy, higher costs and reduced availability of capital, and fewer market participants. Perhaps not a return to oligopoly, but nonetheless more restrictive and less internationally competitive. Conversely, the Productivity Commission proposes to extend ASIC's mandate to competition. ${ }^{219}$ Whilst acknowledging the need for substantive ASIC reform, ${ }^{220}$ it proposes to repeat the error identified by Ashby in 2009 following UK regulator reform in 2007:

\footnotetext{
${ }^{216}$ Ibid app D3, 557.

${ }^{217}$ Ibid 560.

${ }^{218}$ Ibid ch 7, 473 .

${ }^{219}$ Australian Government Productivity Commission, Competition in the Australian Financial System (Draft Report, January 2018).

${ }^{220}$ Ibid 24.
} 
'our regulators have been part of the problem'. ${ }^{221}$

Australia presently is an international outlier in its financial regulation, its desire to become a world financial centre compromised. Fiduciary qualities are implicit in community expectations of trust and loyalty on whom they rely: these qualities need to be the basis of post-Hayne reform. Otherwise, egregious conduct will continue. Australia, as part of the Hayne inspired reform challenge needs to revisit the role of fiduciary law. In the Anglosphere, Canada has implemented reform in its regulation of financial services and products on fiduciary principles. German civil law (now incorporated into EU statutes) provides deep and relevant insight into consumer financial protection.

If Australian directors and financial intermediaries were subject to similar provisions applying in Canada and Germany, they would be less able to hide behind box-ticking compliance processes. They would apply the spirit, principle and intent of the law for the benefit of their consumers.

Much is made in the media and in political circles of the adjective "fiduciary" and the aphorism "best interest". Australian statutes presently have seven interpretations of 'best interest' in different contexts, all different. The proposed addition of mortgage broker best interest duty make it eight, plus varying interpretations in the general law. There is limited public consideration of what these terms mean in practice, or whether the superlative 'best' has any real legal meaning. ${ }^{222}$ Fiduciary law has largely been subsumed by statute to the role of 'legal polyfilla'. For

\footnotetext{
${ }^{221}$ Simon Ashby, The Turner Review on the Global Banking Crisis: A Response from the Financial Services Forum (Nottingham University, 2009) 33. See Millhouse ch 5 s 3.3.2.

${ }^{222}$ David Pollard, 'The Short-form "Best Interests Duty” — Mad, Bad and Dangerous to Know: Part 1 Background, Cowan v Scargull and MNRPF' (2018) 32(2) Trust Law International 106 cited in M Scott Donald, Submission to Royal Commission into Misconduct in the Banking, Superannuation and Financial Services Industry (21 September 2018) [3].
} 
instance, in many respects financial advice consumers are worse off now than before the FoFA reforms. This is largely the result of lobbying.

Whilst Australia has benefited from its Twin Peaks (now Triple Peaks) market based regulatory architecture, its regulation of financial products and financial services requires substantive strategic reform supported by tactical interventions. This includes law reform and reforms designed to enhance productivity in the economy. Without substantive reform, there will not be adequate remedy of the systemic deficiencies in regulation nor of their cyclical manifestations which harm productivity. Present responses to public anger are mainly tactical in nature. That anger is based upon flawed community expectations and a belated understanding that what market participants do can be different from what those participants are expected to do. There is not, in Australia, sufficient understanding by the investing public of competing policy approaches or the benefits that the market based approach has brought to the community. Hardship driven policy change could destroy the economic benefits of an entrepreneurial society.

The four reform themes are: Re-establishment of trust in the investment chain based on fiduciary obligation; Related party transactions, value shifting through tunnelling and conflicts of interest; Architecture for implementation at the financial consumer level — financial planning and wealth management as a profession; and Market conduct regulation for the $21^{\text {st }}$ century (including ASIC reform). To improve Australia's position as a world financial centre, these reform themes are to be given tactical support in disclosure, NBFE corporate governance, MIS, and director and trustees competencies. These four law reform themes, will need to be implemented by four teams reporting to a senior ministerial level special purpose financial consumer-centric Reference Group.

Reform requires significant elapsed time, probably a decade, and it must be sequenced. Strategic reform requires acceptance and implementation by the various stakeholder groups. Tactical reforms can be imposed legislatively. The effectiveness and stability generated by prudential supervision needs to be embedded as a governance value system - a culture - within 
the non-prudentially regulated NBFE sector. Successful implementation aligns interest of provider and consumer: it also changes the role of the regulators: they become educators, supervisors. A healthy culture results in enforcement becoming a last resort. 'The answer to cultural shortcomings is developing high standards of professionalism and excellence'. ${ }^{223}$

The former Corporate Law Economic Reform Program (CLERP) provides an administrative precedent for a series of strategic and tactical reforms which better implement Australia's market based regulatory system and enhance its national productivity. Rather than change the regulatory architecture, reform should be directed at much better implementation of that architecture to eliminate its systemic deficiencies and cyclical manifestations. However, this is not as simple as some suggest. ${ }^{224}$ Australia requires more than incremental change to a failing system. That reflects the magnitude of the task ahead, strategic in scope and objective, each theme supported by tactical statutory interventions.

The benefits of efficiently designed and implemented reform include increased capital availability for Australian industry, less systemic risk for investors, increased financial literacy and knowledge for investors, and harmonisation of Australian financial regulation with international norms. The latter opens the way for financial product portability internationally and more investment options for Australian investors. These reforms open the way for a true private banking industry in Australia. They provide the basis for veracity in public policy uncorrupted by sectional and political influence.

2019 is the end of the beginning of modern Australian financial reform. Choice of road is at hand. Parliament must decide. It must be presented with alternative options. One option stems from the Hayne Royal Commission. This paper presents another option: it proposes the 'Age of Statutes'

\footnotetext{
${ }^{223}$ Colvin and Argent (n 191) 47.

${ }^{224}$ Andrew Godwin and Ian Ramsay, 'Twin Peaks — the legal and regulatory anatomy of Australia's system of financial regulation' (2015) 26 Journal of Banking and Finance Law and Practice 267.
} 
evolve to the 'Age of Trust', firmly rooted in the fertile soil of Donalds' 'nobler qualities' ${ }^{225}$ of fiduciaries. Those fiduciary qualities are implicit in community expectation of trust and loyalty on whom they rely. Those expectations demand that the basis of a modern regulatory regime be based on the four reform themes.

What does Australia wish to achieve as a modern nation? Does it wish to develop its modern story as an entrepreneurial economy competing with its global peers? Does it remain largely reliant on resources extraction and low value employment? Does it want to leverage off innovation and skills? Does it want to develop its SME sector? The answers to these questions determine future public policy in financial services and products regulation. Egregious conduct is contagious. It becomes part of the culture. Does Australia continue its tradition of statutory accretion which has allowed it to flourish? Or do these insights provide a framework? This the cross-road that Parliament must now traverse. It is a binary choice.

If the former road, then this paper predicts that the future will be similar to the recent past. If not, then Australia must undertake reform of financial regulation. Entrepreneurial freedoms must be matched by participant acceptance of fiduciary obligation to guide and enforce market conduct standards: the two are symbiotic. This is evolutionary, some may say revolutionary. It is not revolutionary: it returns Australian financial regulation to a positive culture of trust, honesty and fair dealing. ${ }^{226}$ That is a culture that provides for entrepreneurship, business growth and future employment.

The Law Matters: Australia:

\footnotetext{
${ }^{225}$ Donald, 'Regulating for fiduciary qualities of conduct' (n 33) 142 [1].

${ }^{226}$ See, eg, Bray v Ford [1895-99] All ER 1009, 1011. Lord Herschell noted that: 'human nature being what it is, there is a danger ... of the person holding a fiduciary position being swayed by interest rather than duty, and thus prejudicing those whom he was bound to protect. It has, therefore, been deemed expedient to la[y] down this positive [inflexible] rule.'
} 
needs a system that evades the risk aversion that has become common practice and returns to our roots as an entrepreneurial community breaking new barriers. In the $21^{\text {st }}$ century regulation needs to avoid paternalism without completely abandoning prudent protection of interest. ${ }^{227}$

It is not merely a matter of law, something missed by those who prescribe statutory remedy for every ill. That is the easier route: the quick fix, the instant medication. Evolution is rarely accidental: it is a response to environmental change and the opportunities afforded by new niches. This is the more thoughtful route, taking time to effect cultural change.

Implementation of the four reform themes will require national leadership: from Parliament given form by the Executive. Stakeholder support is essential. A senior Parliamentary ministerial champion supported by the special purpose Reference Group with Commonwealth financial support is required. It could be based on the inoperative but extant Financial Sector Advisory Council. Implementation should be considered as a decade long policy objective working in tandem with the Council of Financial Regulators (CFR). The CFR should have an enhanced mandate to supervise implementation within its regulator stakeholder group. Within each theme, specific tactical legislative interventions in disclosure, national productivity strategy, and governance are needed. These four themes will require considerable statutory support, for consistency guided by the Reference Group and the responsible minister. The Reference Group should sponsor and supervise an independent arbiter to reduce dependence on the court system. The CFR will consider and publicly explain in a comprehensive transparent way what the impact of the reform themes are. It is:

\footnotetext{
${ }^{227}$ Australian Association of Angel Investors, Equity Crowdfunding; Response to the Treasury Consultation Paper (2015).
} 
a vehicle for improving regulators' ability to influence expectation in financial markets. It can build trust in the actions of regulators. But of greatest value is its capacity to be a forum that can test the proposition of a macroprudential intervention....228

Some stakeholders will be challenged: others, qualitative research identifies, will be supportive. All stakeholders must focus on the needs of investors and beneficiaries in the investment chain, not their own sectoral interests. There must be commonality of objective disciplined by a financially empowered literate community led by champions.

2019 must be the start of the 'Age of Trust'. Is Australia up to the challenge?

${ }^{228}$ Australian Government Productivity Commission, Competition in the Australian Financial System (Draft Report, January 2018) 476. This refers specifically to a competition advocate but can be applied more broadly to each of the reform themes and their tactical manifestations. 